\title{
Comparison of soil bacterial community and functional characteristics following afforestation in the semi-arid areas
}

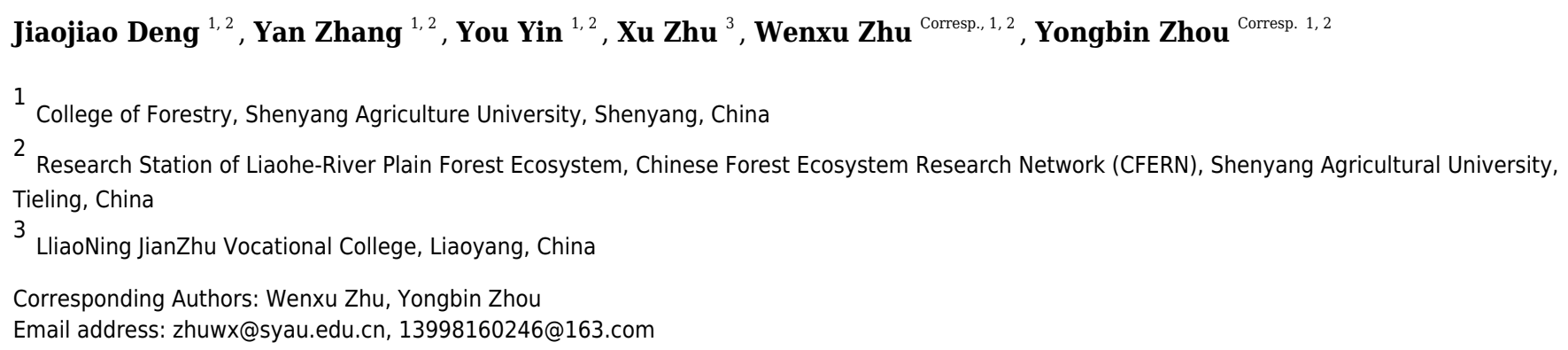

Changes in soil bacterial communities, which are crucial for the assessment of ecological restoration in Chinese plantations, have never been studied for the 'Three North Shelterbelt' project in the semi-arid areas. We used high-throughput sequencing of the 16S rDNA gene to investigate the soil bacterial community diversity, structure, and functional characteristics in three plantation forests, including Populus $\times$ canadensis Moench (PC), Pinus sylvestris var. mongolica (PS), and Pinus tabuliformis (PT). In addition, soil environment factors were measured. There were distinct differences in soil characteristics among different plantation forests. Compared to PS and PT, PC had a higher soil pH, dissolved organic carbon (DOC), and available $\mathrm{P}$, as well as a lower $\mathrm{C} / \mathrm{N}$ ratio. Furthermore, afforestation with different tree species significantly altered the abundance of Proteobacteria, and Chloroflexi in the soil, and its influence on the bacterial diversity indices. The bacterial community compositions and functional groups related to $\mathrm{C}$ and $\mathrm{N}$ cycling from PS, and PT were grouped tightly, indicating that the soil bacterial phylogenetic distance of PS and PT were closer than that between PS plus PT and PC. Our results implied that the soil characteristics, as well as the diversity, compositions and functions related to $\mathrm{C}$ and $\mathrm{N}$ cycling of soil bacterial community obviously differed following afforestation, especially between PC and PS plus PT, which in turn enormously established the correlation between the soil microbial community characteristics and the afforestation tree species. 
1 Comparison of soil bacterial community and functional characteristics following afforestation in

2 the semi-arid areas

3 Jiaojiao Deng ${ }^{1,2}$, Yan Zhang ${ }^{1,2}$, You Yin ${ }^{1,2}, X_{\text {X Zhu }}^{3}$, Wenxu Zhu ${ }^{1,2 *}$,Yongbin Zhou ${ }^{1,2 *}$

$4{ }^{1}$ College of Forestry, Shenyang Agriculture University, Shenyang, China.

$5 \quad{ }^{2}$ Research Station of Liaohe-River Plain Forest Ecosystem, Chinese Forest Ecosystem Research

6 Network (CFERN), Shenyang Agricultural University, Tieling, China.

$7 \quad{ }^{3}$ LliaoNing JianZhu Vocational College, Liaoyang, China.

*Corresponding Author

Wenxu Zhu, Yongbin Zhou

14 No. 120, Dongling Road, Shenhe Distinct, Shenyang, Liaoning Provience, 110161, China

15 Email address: zhuwx@,syau.edu.cn, 13998160246@163.com 


\section{Abstract}

Changes in soil bacterial communities, which are crucial for the assessment of ecological restoration in Chinese plantations, have never been studied for the 'Three North Shelterbelt' project in the semi-arid areas. We used high-throughput sequencing of the 16S rDNA gene to investigate the soil bacterial community diversity, structure, and functional characteristics in three plantation forests, including Populus $\times$ canadensis Moench $(\mathrm{PC})$, Pinus sylvestris var. mongolica (PS), and Pinus tabuliformis (PT). In addition, soil environment factors were measured. There were distinct differences in soil characteristics among different plantation forests. Compared to PS and PT, PC had a higher soil pH, dissolved organic carbon (DOC), and available P, as well as a lower $\mathrm{C} / \mathrm{N}$ ratio. Furthermore, afforestation with different tree species significantly altered the abundance of Proteobacteria, and Chloroflexi in the soil, and its influence on the bacterial diversity indices. The bacterial community compositions and functional groups related to $\mathrm{C}$ and $\mathrm{N}$ cycling from PS, and PT were grouped tightly, indicating that the soil bacterial phylogenetic distance of PS and PT were closer than that between PS plus PT and PC. Our results implied that the soil characteristics, as well as the diversity, compositions and functions related to $\mathrm{C}$ and $\mathrm{N}$ cycling of community characteristics and the afforestation tree species. 
Introduction

Desertification has always been a global important ecological environmental problem in the arid and semi-arid regions (Xin et al., 2004; Torres et al., 2015; Becerril-Piña et al., 2015), that is mainly caused by climate change and human activities in arid, semi-arid and some sub-humid regions (Chasek et al., 2015; Salvati et al., 2015; Wijitkosum, 2016), impacting 25\% of the total terrestrial area (Reynolds et al., 2007; Allington et al., 2010). Desertification has caused a loss of soil nutrients, a decline in land productivity and environmental degradation (Li et al., 2018). This leads to a decline or degradation in sand-stabilization, soil conservation, water resource regulation, carbon sequestration and other desert ecosystem services, and it endangers both regional and national economic, social, and environmental security (Martã-Nez-Valderrama et al., 2016; Sutton et al., 2016). Research sponsored by the United Nations Environment Programme (UNEP) shows that the global economic losses caused by desertification and drought are as high as $\$ 4.2 \times 10^{10}$ USD per year, which is equivalent to all official aid given to Africa in 2009 (United Nations Convention to Combat Desertification (UNCCD), 2011) (Furtado \& Macedo, 2008). With the rapid economic growth, China is also confronted with various environmental problems, including sandstorms, severe desertification, and land degradation in dry northern regions (Liu \& Diamond, 2005).

Numerous researches in arid and semi-arid areas have suggested that afforestation is one of the most commonly used techniques and effective sand-fixing methods to reduce the harm of desertification (Gao et al., 2002; Nunezmir et al., 2015). In addition, afforestation exhibit a significantly positive feedback to the regional environment (Verón \& Paruelo, 2010; Zhang et al., 2014; Peng et al., 2014), successfully combating the desertification and dust storms (Fan et al., 
82

83

84

2014; Tan \& Li, 2015). In order to prevent ecosystem degradation, artificial shrubs and trees have been widely planted in many degraded areas of China (Zhao et al., 2017). Since 1950s, a large desertification control projects have been implemented (Zou et al., 2002; Piao et al., 2005; Qadir et al., 2010). Since 1978, a series of ecological restoration programs have been initiated in China to alleviate these increasingly serious environment problems and to restore degraded land (Zhang et al., 2016), primarily through afforestation and reforestation (Zhang et al., 2014), of which the 'Three North Shelterbelt Development Program (TNSDP)' is the largest afforestation program in the world (Li et al., 2012). This special program in China gives us an advantage of studying the benefits of afforestation in China.

Currently, planted forests in China account for about $31.8 \%$ of the forested area, which is the most of any country in the world (State Forest Administration, 2010). By 2008, afforestation of $1,511,700 \mathrm{hm}^{2}$ of land had been completed in the TNSDP of Liaoning. In this area, 212,200 $\mathrm{hm}^{2}$ of degraded forest was covered, accounting for $13.97 \%$ of the preserved area. Great achievement has been made in the afforestation of the Horqin Sandy Land in northern China (Zuo et al., 2012; Zhao et al., 2014; Ge et al., 2015), and the ecological environment has been considerably improved. Furthermore, afforestation has increased soil organic carbon sequestration in soil (Deng et al., 2006; Zhou et al., 2014). During vegetation recovery, soil characteristics have also been identified as the main factors driving plant growth, plant production, and dune ecosystem function (Zuo et al., 2008; Zuo et al., 2009; Qiu et al., 2018). A variety of researchers have focused on the influences of vegetation on the soil water content (Yang et al., 2018) and soil characteristics (Deng et al., 2017).

Compared with the physical and chemical properties of soil, soil microorganisms are more efficient and dynamic indicators of soil quality (Mg et al., 2010; Bridge \& Spooner, 2001). Soil microorganisms play a vital role in soil processes, which can profoundly impact the main biogeochemical cycles of $\mathrm{C}$ and $\mathrm{N}$, as well as provide protection to larger organisms through the formation of biofilms (Chatterjee et al., 2008; Ritz et al., 2009; Burton et al., 2010). Previous research suggests that the soil microbial distribution is regulated by the different revegetation types 
109

110

111

112

113

114

115

116

117

118

119

120

121

122

123

124

125

126

127

128

129

130

131

132

133

134

135

(Deng et al., 2019). In addition, soil characteristics play important roles in shaping the soil bacterial community diversity and structure in the terrestrial ecosystems (Liu et al., 2018). Extensive studies have indicated that tree species and soil characteristics influence the microbial community structure and compositions (Ding et al., 2017). Within the fragile local ecological environment, there is also a close correlation between the soil biological properties and vegetation types. Thus, it is of great significance to study the characteristics of soil microorganisms in different plantation forests used for sand fixation forest (Wang et al., 2016). This information will allow for a better understanding of how soil improvement effects sand fixation forest and prevents land desertification. Previous findings have reported that grassland afforestation changes the chemical properties and composition of the soil, as well as the ecological functions of the soil bacterial communities. And these effects of afforestation on the microorganisms have been modulated by changes in soil chemical characteristics (Wu et al., 2019). Moreover, the forest soil habitat is an efficient means to restore local vegetation and studying this area can shed new light on the distribution of local soil eukaryotic microorganisms in semi-arid areas (Zhao et al., 2018).

Northwest Liaoning has an arid climate, frequent gales, water shortage and low vegetation cover. It is also the key governance area of the TNSDP. In recent decades, Populus $\times$ canadensis Moench (PC), Pinus sylvestris var. mongolica (PS), and Pinus tabuliformis (PT) have become the main afforestation tree species and widely used for afforestation in the "Three North Shelterbelt" due to their strong stress resistance, ability to accelerate ecological rehabilitation and improve ecological stability. Previously numerous studies in shelterbelt have focused primarily on the aboveground ecosystem, and the soil physicochemical characteristics (Wang et al., 2014; Zhou et al., 2016). However, variations in the soil bacterial communities, which are crucial for the assessment of ecological restoration in plantations in this area, have never been studied. Therefore, we selected a typical artificial shelterbelt in the semi-arid area of northwestern Liaoning as the study area. The soil bacterial community diversity, compositions and functional characteristics were analyzed for different plantation forests composed of Populus $\times$ canadensis Moench, Pinus sylvestris var. mongolica, and Pinus tabuliformis. We propose the following hypotheses: 1) the 
136

137

138

139

140

141

142

143

144

145

146

147

148

149

150

151

152

153

154

155

156

157

158

159

160

161

162

three different plantation forests harbor different soil bacterial diversity and community structures;

2) the functional groups related to $\mathrm{C}$ and $\mathrm{N}$ cycling differ between PC and PS plus PT; and 3) consistent differences occur in the soil bacterial community and functional characteristics following afforestation. This research provides a reference for vegetation restoration and sustainable management of artificial forests in this area. Furthermore, this study has important the theoretical and practical significance for the selection of tree species used for sand fixation in semiarid regions. Our results provide a scientific basis for the recovery of degraded soils.

\section{Material and methods}

Sites description

Research was conducted at Fujia forest farm, Changtu county, northwest of Liaoning province $\left(123^{\circ} 32^{\prime} \mathrm{E} \sim 123^{\circ} 55^{\prime} \mathrm{E}, 42^{\circ} 53^{\prime} \mathrm{N} \sim 43^{\circ} 21^{\prime} \mathrm{N}\right)$. This area is located at the southern edge of Horqin Sandy Land and belongs to the Liaohe alluvial plain. The soil texture is characterized by Arenosols (Lv et al., 2018). The study area is located at an attitude of $91.1 \sim 173.4 \mathrm{~m}$, with the relatively flat topography and a small amount of elliptic or circular dune distribution. The climate in this region is classified as a temperate semi-humid semi-arid continental climate ( $\mathrm{Lu}$ et al., 2017), with long and cold winters, and hot summers. There is little rainfall, with an average annual precipitation of 400 to $550 \mathrm{~mm}$ that is concentrated in July to August. The average annual evaporation is approximately $1843 \mathrm{~mm}$. The average temperature is $7^{\circ} \mathrm{C}$ with extreme maximum and minimum temperature of $35.6{ }^{\circ} \mathrm{C}$ and $-31.5^{\circ} \mathrm{C}$. In recent decades, Populus $\times$ canadensis Moench, Pinus sylvestris var. mongolica, and Pinus tabuliformis were the main plantation forests in the "Three North Shelterbelt" (Fig. 1). Prior to afforestation, the vegetation type was Arachis hypogaea (peanut) farmland, and the site information was shown in Table 1.

\section{Soil sampling}

Three independent replicate plots $(20 \mathrm{~m} \times 20 \mathrm{~m})$ within the same climate were established in August 2018 for each forest type. The distance between each sampling plot was greater than $50 \mathrm{~m}$ but less than $200 \mathrm{~m}$. To ensure the representativeness of soil samples, 10-15 soil cores of topsoil ( $0 \sim 10$ $\mathrm{cm})$ were collected for each triplicate plot using soil auger with an "S" shape. After removing the 
163 litter layer, the soil cores were combined to one composite sample, giving a total of 9 samples. All 164 soil samples were stored on ice box after being sealed in plastic bags for transport to the laboratory. 165 In the laboratory, the samples were sieved through a $2 \mathrm{~mm}$ mesh to remove plant roots, stones, 166 litter, and other debris. Samples were subsequently divided into three parts. One part was air-dried 167 for analysis of soil characteristics, including soil $\mathrm{pH}$, the contents of total carbon (C), total nitrogen $168(\mathrm{~N})$, and available phosphorus (P). The second part was stored at $4{ }^{\circ} \mathrm{C}$ for DOC analysis, and the 169 third part was stored at $-80{ }^{\circ} \mathrm{C}$ for DNA extraction.

\section{Measurement of soil characteristics}

171 The soil $\mathrm{pH}$ was analyzed using an electrode $\mathrm{pH}$ meter in the soil-water $(1: 5 \mathrm{w} / \mathrm{v})$ suspension (Bao, 2000; Ren et al., 2017). The contents of soil total $\mathrm{C}$ and total $\mathrm{N}$ were determined using an elemental 173 analyzer (Elementar, Germany) (Schrumpf et al., 2011). The concentrations of available P was determined using the extraction-flame photometry with a $0.5 \mathrm{M} \mathrm{NaHCO}_{3}$ extraction (Emteryd, 1989). Additionally, the content of dissolved organic carbon (DOC) was extracted from fresh soil using deionized water (1:5 w/v) (Gong et al., 2009) and determined via a TOC analyzer (Multi N/C 3100, Analytik Jena AG).

\section{Soil DNA Extraction and 16S rDNA Sequencing}

DNA was extracted from $0.5 \mathrm{~g}$ of soil using the FastDNA SPIN Kit for Soil (MP Biomedicals, Santa Ana, CA, USA), following the manufacturer's instructions. A NanoDrop ND-1000 spectrophotometer (Thermo Fisher Scientific, Waltham, MA, USA) was used to determine the quantity and quality of the extracted DNA. PCR was performed to target V3-V4 hypervariable region of the bacterial 16S rRNA genes was constructed to amplify, with the forward primer 338F (5'-ACTCCTACGGGAGGCAGCA-3') and the reverse primer 806R (5'GGACTACHVGGGTWTCTAAT-3') (Deng et al., 2018). PCR amplifications were carried out in two steps. Firstly, each of three independent $25 \mu \mathrm{l}$ reactions per DNA sample contained $5 \mu$ l of Q5 High-Fidelity GC buffer $(5 \times) ; 5 \mu$ of Q5 reaction buffer $(5 \times) ; 1 \mu \mathrm{l}(10 \mathrm{uM})$ of forward primer, 1 $\mu \mathrm{l}(10 \mathrm{uM})$ of reverse primer; $0.25 \mu \mathrm{l}(5 \mathrm{U} / \mu \mathrm{l})$ of Q5 High-Fidelity DNA Polymerase; $2 \mu \mathrm{l}$ of dNTPs $(2.5 \mathrm{mM}) ; 2 \mu \mathrm{l}$ of DNA Template (40-50 ng); and $8.75 \mu \mathrm{l}$ of $\mathrm{ddH}_{2} \mathrm{O}$ (Deng et al., 2018). 
190

191

192

193

194

195

196

197

198

199

200

201

202

203

204

205

206

207

208

209

210

211

212

213

214

215

216

Cycling conditions were as follows: one cycle of denaturation at $98^{\circ} \mathrm{C}$ for $5 \mathrm{~min}$; then denaturation at $98{ }^{\circ} \mathrm{C}$ for $15 \mathrm{~s}$, annealing at $55^{\circ} \mathrm{C}$ for $30 \mathrm{~s}$, and extension at $72{ }^{\circ} \mathrm{C}$ for $30 \mathrm{~s}(25$ cycles $)$; and with a final extension at $72{ }^{\circ} \mathrm{C}$ for 5 min. Agencourt AMPure Beads (Beckman Coulter, Indianapolis, IN) and PicoGreen dsDNA Assay Kit (Invitrogen, Carlsbad, CA, USA) were used to purify and quantify PCR amplicons. Amplicons were then pooled at equal concentrations after the individual quantification step, and sequencing of pair-end $2 \times 300$ bp was performed using the Illlumina MiSeq platform with the MiSeq Reagent Kit v3 (Shanghai Personal Biotechnology Co., Ltd, Shanghai, China).

\section{Functional Prediction using FAPROTAX}

The database of Functional Annotation of Prokaryotic Taxa (FAPROTAX), which is based on the available functional information in the existing microbiology literature, summarize the names of related species from functional classification and annotation information. FAPROTAX can be used to extrapolate functions of cultured prokaryotes to estimate metabolic or other ecological relevant functions, which is more suitable for the functional annotation and prediction of the biogeochemical cycle of environmental samples. The annotated operational taxonomic unit (OTU) table from the Silva database was read, and the annotated OTU information was matched with the species information in the database using python program and the predicted functions was output. The details of this approach are provided by Louca et al. $(2016,2017)$. The relative abundances of the functional groups in each sample was calculated as the cumulative abundance of OTUs assigned to each functional group, which was obtained by normalizing the cumulative abundance of OTUs correlated with at least one function. Thus, functional annotation of the OTUs was established based on FAPROTAX. We then investigated potential functions involved in geographical location and environmental conditions.

\section{Bioinformatics and processing of sequencing data}

The QIIME software (v1.9.0) and the UPARSE pipeline (Zhong et al., 2015) were used to analyze the raw data obtained from Illumina sequencing. The bacterial raw data was submitted to the NCBI Sequence Read Archive (SRA) under accession number PRJNA495735. The operational 
217 taxonomic assignment of OTUs with similarities $>97 \%$ was conducted using the UPARSE pipeline

218 (Edgar, 2013). Then the operational taxonomic classification and identity of OTUs were 219 determined using a BLAST algorithm against sequences within the Silva Database via QIIME 220 software (Kõljalg et al., 2013). OTU-level alpha diversity indices, such as Simpson index, Chao1 221 index, Shannon index, and ACE index were computed using the OTU table in QIIME (Caporaso 222 et al., 2010).

\section{Statistical Analysis}

224 Among samples, the unique and shared OTUs of the soil bacterial community were used to create 225 Venn diagrams using the R (R v.3.4.4) with the "VennDiagram" package (Zaura et al., 2009). The 226 heatmap representation of the top 50 classified bacterial genera in each sample was established 227 using R (R v.3.4.4) with the "gplot" and "pheatmap" packages (R Development Core Team, 2009). 228 The relationships between soil characteristics and the bacterial community functions related to C

229

230

231

232

233

234

235

236

237

238

239

240

241

242

243 and N cycling based on Spearman's rank correlation analysis were built using R (R v.3.4.4) with the "psych" and "corrplot" packages (R Development Core Team, 2009). The differences in bacterial community structure across samples were established through beta diversity analysis and visualized via nonmetric multidimensional scaling (NMDS) based on unweighted UniFrac distance metrics (Lozupone et al., 2007).

Multifactorial ANOVA (MANOVA) and Canonical correspondence analysis (CCA) were applied to analyze the effects of tree species on the all measured soil characteristics. Multiple comparisons of means at a 95\% confidence interval were performed using Tukey's honest significance difference (HSD) post-hoc test. Soil bacterial diversity and relative abundances were analyzed in SPSS (v 19.0) using a one-way analysis of variation (ANOVA) and least significant difference (LSD) multiple comparison tests (Banerjee, 2016). Spearman's rank correlation was used to estimate the relationships between soil characteristics and soil bacterial community diversity. The similarity patterns as the functional groups of bacterial community were analyzed with Principal component analysis via the STAMP software (Parks et al., 2014). The linkages between soil environmental factors and bacterial community composition at the phylum level were 
244 performed by canonical correspondence analysis (CCA) via Canoco 4.5 (Braak \& Smilauer, 2002).

245

246

247

248

249

250

251

252

253

254

255

256

257

258

259

260

261

262

263

264

265

266

267

268

269

270

\section{Results}

\section{Soil characteristics in different plantation forests}

Tree species had a strong significant effect on all the soil $\mathrm{pH}(F=6.58, P=0.031)$, total $\mathrm{C}(F=$ $30.54, P=0.001)$, DOC $(F=6.02, P=0.037)$, total N $(F=6.47, P=0.032), \mathrm{C} / \mathrm{N}(F=45.49, P<$ 0.001), and available $\mathrm{P}(F=78.06, P<0.001)$ (Table 2$)$. There were distinct differences about soil chemical characteristics among the three plantation forests. The soil $\mathrm{pH}$ ranged from 5.53 to 5.92 . The highest $\mathrm{pH}$ value was occurred in $\mathrm{PC}$ with 5.92, and significantly higher than PS and PT $(P<$ 0.05). The soil DOC was highest in PC with $105.46 \mathrm{~g} \cdot \mathrm{kg}^{-1}$, and significantly higher than in PS and PT $(P<0.05)$. Soil total $\mathrm{C}$ and total $\mathrm{N}$ concentrations in PS were the highest with $12.00 \mathrm{~g} \cdot \mathrm{kg}^{-1}$, and $1.05 \mathrm{~g} \cdot \mathrm{kg}^{-1}$, respectively, followed by PT. And both of them occurred significantly higher than PC $(P<0.05)$. The maximum value of the $\mathrm{C} / \mathrm{N}$ ratio occurred in PT with 11.79 , followed by PS with 11.41, and lowest in PC with 9.15. No significant differences were observed in the soil total $\mathrm{C}$ content and $\mathrm{C} / \mathrm{N}$ ratio between PS and PT $(P>0.05)$. Soil available $\mathrm{P}$ was highest in $\mathrm{PC}$ with $16.00 \mathrm{mg} \cdot \mathrm{kg}^{-1}$, which was significantly higher than those of PS and PT $(P<0.05)$ (Table 2). Compared to PS and PT, the PC had the highest soil $\mathrm{pH}$ value, DOC, and available P, as well as the lowest $\mathrm{C} / \mathrm{N}$ ratio.

The first two axes of the CCA accounted for $84.3 \%$ of the total variance. The CCA plot showed a clear separation in the space among the three plantation forests. In fact, the PC distinctly separated from PS, and PT, especially along CCA1 (Fig. 2). The investigated soil characteristics also clearly separated into the quadrants. Soil total $\mathrm{N}$ was situated in the first quadrant; available $\mathrm{P}$ and soil $\mathrm{pH}$ were in the second quadrant; soil $\mathrm{pH}$ was in the third quadrant; soil total $\mathrm{C}$ and $\mathrm{C} / \mathrm{N}$ ratio were in the fourth one (Fig. 2). The results illustrated that the different forest types had different soil characteristics, significantly different between PC and PT plus PS.

\section{Soil bacterial community diversity under different plantation forests}

There were significant differences among different plantation forests regarding soil total $\mathrm{C}$ and total $\mathrm{N}$ contents ACE index and Chaol index $(F=7.64, P=0.02 ; F=7.92, P=0.02$; Table 3$)$. 
271 The maximum values of the ACE index and Chao1 index occurred in PS with 4074.80, and 272 3952.39, respectively, followed by PT and PC. The soil bacterial Shannon index and Simpson 273 index among three plantation forests significantly differed $(F=6.89, P=0.03 ; F=5.68, P=0.04$;

274 Table 3). The Shannon index and Simpson index were lowest in PT with 10.09 and 0.996,

275

276

277

278

279

280

281

282

283

284

285

286

287

288

289

290

291

292

293

294

295

296

297

respectively. The Spearman's rank correlations indicated that soil total N significantly positively correlated with the Chao 1 index $(\mathrm{r}=0.78, P<0.05)$ and ACE index $(\mathrm{r}=0.83, P<0.01)$. The Simpson index was significantly positively related with soil available $\mathrm{P}(\mathrm{r}=0.77, P<0.05)$, and DOC contents $(\mathrm{r}=0.67, P<0.05)$, while, the Simpson index was highly negatively correlated with the $\mathrm{C} / \mathrm{N}$ ratio $(\mathrm{r}=-0.73, P<0.05)($ Table 4$)$.

\section{Soil bacterial community structure in different plantation forests}

After quality trimming and chimera removal, 48,848, 51,532, and 52,395 high-quality sequences were generated from the PC, PS, and PT sites, respectively. Rarefaction curves for all the soil samples were shown in Fig. S1. As shown in the Venn diagram (Fig. 3), the total number of shared bacterial OTUs in PC, PS, and PT was 1,355. The number of bacterial OTUs shared between two sites was 1,503 for PT and PS, 744 for PS and PC, and 253 for PT and PC. The unique OTUs harbored in PC, PS and PT were 1486, 764 and 990, respectively.

Sequences analysis showed a total of 29 phyla, and 793 genera within the three plantation forest samples. Nine dominant phyla (relative abundance $>1 \%$ ) were observed, of which the total average relative abundances represented more than 95\%. Proteobacteria was the most dominant bacterial phylum (31.01\%), followed by Actinobacteria (23.76\%), Acidobacteria (20.08\%), Gemmatimonadetes (9.17\%), Chloroflexi (8.07\%), Firmicutes (1.52\%), Planctomycetes (1.45\%), Bacteroidetes (1.18\%), and Verrucomicrobia (1.07\%) (Fig. 4). The average relative abundances of the Proteobacteria subgroups (Alpha-, Beta-, Gamma-, and Delta-Proteobacteria) were 18.90\%, $5.45 \%, 3.10 \%$, and $3.56 \%$, respectively (Fig. S2). The relative abundances of Proteobacteria and Chloroflexi varied significantly $(P<0.05)$ among the different forest types, with the highest abundances in PC with 34.78\% and 10.02\%, respectively (Fig. 4A). No significant differences were observed for other phyla among the different plantation forests $(P>0.05)$. 
298

299

300

301

302

303

304

305

306

307

308

309

310

311

312

313

314

315

316

317

318

319

320

321

322

323

324

At the genus level, 13 dominant bacterial genera (relative abundances $>1 \%$ ) were observed, namely RB41, Gemmatimonas, Sphingomonas, Crossiella, Jatrophihabitans, Variibacter, Rhizomicrobium, Pseudomonas, Bryobacter, Nitrobacter, Candidatus-Solibacter, Haliangium, and Pseudonocardia, accounting for more than $20 \%$ of the total relative abundances (Fig. 4B). The average relative abundances of Jatrophihabitans, Rhizomicrobium, Bryobacter, CandidatusSolibacter, and Haliangium were significantly different among the three plantation forests $(P<$ $0.05)$.

\section{Effects of tree species on the compositions of the soil bacterial community}

A cluster heatmap analysis was used to analyze the differences in the bacterial community compositions among the three plantation forests at the genus level (Fig. 5). The relative abundance and distribution of soil bacteria in different plantation forests changed significantly. Results showed that the soil samples were divided into two groups: one group contained the PT and PS, and the other group was PC. In order to show the bacterial community structures of PC, PS and PT, NMDS plot based on the unweighted uniFrac metric was calculated (Fig. 6). The NMDS plot also showed that the samples were classified into two large groups, one group corresponding to the communities from the PS, and PT, and the other group from PC. The samples from the PS and PT were grouped tightly, indicating that they shared a high similarity in their bacterial compositions. Furthermore, the PS and PT tended to be separate from the PC, especially along NMDS1, which contributed to $45.17 \%$ of the variance. Both analyses demonstrated that different plantation forests had different influences on the soil bacterial communities. Moreover, the phylogenetic relationship of the PT and PS was closer than those between the PT plus PS and PC.

\section{Effects of soil environment factors on the soil bacterial community compositions}

Results of the CCA showed that soil bacterial community structure had significant correlations between and soil characteristics (Fig. 7). At the phylum level, the first ordination CCA axis (CCA1) was strongly correlated with $\mathrm{pH}(\mathrm{r}=0.71)$, total $\mathrm{C}(\mathrm{r}=-0.87)$, DOC $(\mathrm{r}=0.71)$, total N $(\mathrm{r}$ $=-0.71), \mathrm{C} / \mathrm{N}(\mathrm{r}=-0.85)$, and available $\mathrm{P}(\mathrm{r}=0.91)$, explaining $54.5 \%$ of the total variability of the bacterial community structures. Both axes together explained $81.5 \%$ of the variation (Fig. 7A). 
325

326

327

328

329

330

331

332

333

334

335

336

337

338

339

340

341

342

343

344

345

346

347

348

349

350

351

At the genus level, the first ordination CCA axis (CCA1) was strongly correlated with total $\mathrm{C}(\mathrm{r}=$ $0.58), \mathrm{C} / \mathrm{N}(\mathrm{r}=0.76)$, and available $\mathrm{P}(\mathrm{r}=-0.74)$, explaining $55.7 \%$ of the total variability of the bacterial community structures. Both axes together explained $76.5 \%$ of the variation (Fig. 7B). Thus, soil DOC, C/N, and available $\mathrm{P}$ were important variables that played vital roles in the shaping of the bacterial communities.

The relative abundances of Proteobacteria $(\mathrm{r}=0.83, P<0.01)$ and Bacteroidetes $(\mathrm{r}=0.78, P$ $<0.05)$ had significantly positive correlations with the DOC content. The relative abundances of Proteobacteria $(\mathrm{r}=-0.67, P<0.05)$, Chloroflexi $(\mathrm{r}=-0.68, P<0.05)$, and Bacteroidetes $(\mathrm{r}=-0.77$, $P<0.05)$ were significantly negatively correlated with $\mathrm{C} / \mathrm{N}$. In contrast, the relative abundances of Proteobacteria $(\mathrm{r}=0.68, P<0.05)$, Chloroflexi $(\mathrm{r}=0.78, P<0.05)$, and Bacteroidetes $(\mathrm{r}=$ $0.70, P<0.05)$ were positively correlated with available $P$. The relative abundance of Verrucomicrobia was dramatically negatively correlated with soil $\mathrm{pH}(\mathrm{r}=-0.83, P<0.01)$, while, Verrucomicrobia was significantly positively correlated with total $\mathrm{C}(\mathrm{r}=0.90, P<0.01)$, and total $\mathrm{N}(\mathrm{r}=0.83, P<0.01)$. The relative abundance of Planctomycetes showed a significantly positive correlation with $\mathrm{C} / \mathrm{N}(\mathrm{r}=0.70, P<0.05)$, and negative correlation with available $\mathrm{P}(\mathrm{r}=0.88, P<$ 0.01) (Table 5).

\section{Bacterial functional annotation and distribution in different plantation forests}

According to the classification annotation results of the $16 \mathrm{~S}$ rDNA sequences, a total of 51 functional groups were identified using FAPROTAX. These functional groups contained 5063 OTUs, and OTUs per functional group were listed in Table S1. We examined 13 ecological functional groups related to the $\mathrm{C}$ cycling, including chemoheterotrophy, aerobic chemoheterotrophy, phototrophy, photoautotrophy, photoheterotrophy, anoxygenic photoautotrophy S oxidizing, anoxygenic photoautotrophy, cellulolysis, oxygenic photoautotrophy, methylotrophy, methanol oxidation, hydrocarbon degradation, and methanotrophy (Table S2). The PCA plot showed that the functional groups related to C cycling in PT and PS were separate from those of PC, especially along PCA1 (Fig. 8A). Additionally, we examined 12 ecological functional groups connected to the $\mathrm{N}$ cycling, including nitrification, 
352 nitrate reduction, nitrogen respiration, nitrate respiration, aerobic nitrite oxidation, aerobic

353 ammonia oxidation, nitrogen fixation, nitrite respiration, nitrate denitrification, nitrite

354 denitrification, nitrous oxide denitrification, and denitrification (Table S3). The PCA plot showed

355 that the functional groups related to N cycling in PT and PS were separated from those of PC,

356 especially along PCA2 (Fig. 8B), indicating that the functional groups of PC differed from those

357 of PS plus PT. We performed the Spearman's rank correlation analysis to explore the relationships

358 between the microbial functional groups and the six key environmental variables (Fig. 9). Soil pH

359 value, total $\mathrm{C}$, total $\mathrm{N}, \mathrm{C} / \mathrm{N}$, and available $\mathrm{P}$ were the main factors influencing the functional groups

360 related to $\mathrm{C}$ cycling (Fig. 9A). Whereas, total $\mathrm{C}$ was the main factor influencing the functional

361 groups related to $\mathrm{N}$ cycling (Fig. 9B).

\section{Discussion}

\section{Soil chemical characteristics following afforestation with different tree species}

364 Afforestation with different plantation forests had significant difference in soil conditions. PC had 365 the highest $\mathrm{pH}$ value, when compared to PS and PT (Table 2), which was similar to the study 366 demonstrating that the soil in pine stands had a lower $\mathrm{pH}$ than the oak and birch tree stands 367 (Yoshimura et al., 2008). This difference might be the result of higher litter acidity in coniferous forests (Augusto et al., 2002). We observed that soil DOC in PC was higher than that in PS and PT. Our results were consistent with a previous study stating that soil organic matter and nitrogen were higher in broadleaf forests than those in coniferous forests (Jiang et al., 2012). Previous findings had established that the both tree species and afforestation time dramatically influenced on soil characteristics (Kim et al., 2018; Kang et al., 2018). In our study, the $\mathrm{C} / \mathrm{N}$ values decreased in the order of PT $>$ PS $>$ PC, which was consistent with a previous finding that coniferous forests (pine) soil contained more carbon and had a higher $\mathrm{C} / \mathrm{N}$ ratio than broadleaf forests (Yoshimura et al., 2008). The potential role of different forest types in variation of soil $\mathrm{C} / \mathrm{N}$ ratio was also supported by previous finding (McGroddy et al., 2004). In summary, the soil characteristics following afforestation with different tree species in the same area exhibited obvious differences, especially between PC and PS plus PT. 
379

380

381

382

383

384

385

386

387

388

389

390

391

392

393

394

395

396

397

398

399

400

401

402

403

404

405

\section{The bacterial community diversity response to different plantation forests}

Similar to the soil characteristics, the Chao 1 index, and ACE index in PC were significantly lower than those in PS and PT $(P<0.01)$. Simultaneaously, here we found that the Simpson index and Shannon index existed significant differences among different plantation forests $(F=6.89, P=$ $0.03 ; F=5.68, P=0.04$; Table 3 ). This result might be due to the differences in the chemical compositions and decomposition rate of the litter (Kang et al., 2018). The Spearman's rank correlations illustrated the Chao 1 index and ACE index existed significantly positively correlated with soil total $\mathrm{N}$, which was similar to the research from northeast China that reported that the $\mathrm{H}^{\text {' }}$ value was positively correlated with the total N (Hui et al., 2014). The Simpson index was significantly positively related to soil available $\mathrm{P}$, while, a previous study suggested that there was no significant correlation between diversity indices and P content (Wang et al., 2018). These results verified that there were significant differences in soil bacterial diversity among different forest lands.

\section{The bacterial community compositions response to different plantation forests}

The abundances of dominant bacterial phyla varied among the different plantation forests. In our study, Proteobacteria was the most dominant group, which was similar to the findings from Chinese pine plantations on the Loess Plateau (Dang et al., 2017), while, the research from Wulai forest reported Acidobacteria was the dominant member (Lin et al., 2014). Owing to differences in the lifestyles of Proteobacteria and Acidobacteria, they can be used as indicators of nutritional status (Hartman et al., 2008). In our study, the relative abundance of Proteobacteria in PC was significantly higher than that in PS and PT. In addition, the relative abundances of Proteobacteria had significantly positive correlations with DOC content. Our results concurs with previous findings establishing that the availability of carbon was positively related with the abundance Proteobacteria (Fazi et al., 2005; Fierer et al., 2007). In our study, Alphaproteobacteria was the dominant taxa at the class level. This is in agreement with the results obtained from a boreal peatland in Central Finland (Sun et al., 2014).

The phylum Acidobacteria is abundant in various soil environments (Zimmermann et al., 
406

407

408

409

410

411

412

413

414

415

416

417

418

419

420

421

422

423

424

425

426

427

428

429

430

431

432

2005; Araujo et al., 2012; Meng et al., 2013). In our study, the abundance of Acidobacteria was relatively higher in the soil communities of PS and PT than that in PC, which was consistent with a previous investigation that the relative abundance of Acidobacteria was relatively higher in the coniferous forest than those of broadleaf forest (Christianl et al., 2008). Soil pH is generally considered as a key factor in shaping bacterial community structures (Preem et al., 2012). Many researches have established that the relative abundance of the Acidobacteria is dramatically associated with acidic soils (Jones et al., 2009), and more specifically, when the $\mathrm{pH}$ is lower than 5.5, Acidobacteria abundance increases (Lauber et al., 2009). However, our results found that the soil $\mathrm{pH}$ had no relation to the relative abundance of Acidobacteria, which might be due to the narrow range of $\mathrm{pH}$ from 5.53 to 5.92 (Table 2). PC stand had the highest abundance of Proteobacteria and lowest abundance of Acidobacteria. In consideration of the comparatively higher relative abundance of Proteobacteria observed in the copiotrophic soils and the relatively higher Acidobacteria abundance obtained in the oligotrophic soils (Fierer et al., 2007), we suggested that the PC plantation improved the soil nutrient conditions with lower $\mathrm{C} / \mathrm{N}$ value. Gemmatimonadetes was the dominant bacterial community in our research, previous researches illustrated that Gemmatimonadetes has been found in arid soils, such as grassland, prairie, and pasture soil, as well as pine soils (DeBruyn et al., 2011). In our study, the relative abundances of Chloroflexi, and Bacteroidetes were positively correlated with available $\mathrm{P}$, and available $\mathrm{P}$ might be one of the important factors influencing the bacterial community. Identically, previous findings have indicated that the phosphorus content has an effect on community structures (Fierer et al., 2007; Bergkemper et al., 2016).

The results of clear differentiation provided by the heatmap (Fig. 5) and NMDS (Fig. 6) plots illustrated that significant differences in the bacterial community compositions were observed among PS, PT and PC. The soil bacterial communities of the PT and PS sites were similar to each other, indicating that the hierarchical clustering distance between two coniferous forests was shorter than the distance between the coniferous and broadleaf forests. Our results were agreement with previous study which have established that the compositions of the soil bacterial community 
433 in hardwood forest differed from those in conifer forests (Lin et al., 2011; Ushio et al., 2008), 434 which could release different quality and quantity of litter and root exudates (Sauheitl et al., 2010).

435 In addition, the compositions of soil bacteria between PS and PT were also different. These results 436 confirmed our hypothesis that the three different plantation forests harbored different soil bacterial 437 community diversity and structure, suggesting that afforestation tree species had correlation with 438 soil bacterial community, which was consistent with previous findings (Ren et al., 2016; Gunina 439 et al., 2017).

\section{The bacterial functional groups response to different plantation forests}

441 The $\mathrm{C}$ and $\mathrm{N}$ cycle in the terrestrial ecosystem and its regulatory mechanism are the hot topics in 442 the science research of soil ecology and global change ecology (Maia et al., 2010). It is known that 443 soil bacterial communities play an important role in biogeochemical cycles (Jenkins et al., 2017). 444 In our study, we examined 13 functional groups related to $\mathrm{C}$ cycling. In contrast, previous study from a temperate deciduous broadleaved forest and a tropical mountain rainforest detected eight ecological functional groups connected with the carbon cycle (Wei et al., 2018). Soil nitrogen fixation, nitrification, denitrification, ammonification, and other major nitrogen transformation processes are mainly mediated by soil bacteria (Yoon et al., 2015). And the soil nitrogen cycle, especially the biological nitrification and denitrification processes, can affect the production and emission of greenhouse gases, such as $\mathrm{CO}_{2}, \mathrm{CH}_{4}$, and $\mathrm{N}_{2} \mathrm{O}$ (Gregorich et al., 2015). To some extent, the denitrifying community of bacteria plays a vital role in the soil nitrogen cycle, and the relative abundances of specific OTUs are more valuable in predicting community function (Bent et al., 2016). In our study, the functional groups of denitrification were significantly higher in the PS than PT and PC $(P<0.05)$. For soil bacterial function, the functional groups related to $\mathrm{C}$ and $\mathrm{N}$ cycling in PT and PS were distinctly separate from those of PC, indicating that the functional groups of the broadleaf forest differed from those of the coniferous forests. Different plantation tree species could distinctly affect the community compositions of decomposers (Kubartová et al., 2007). Due to the existence of functional gene redundancy, these functional profiles are observed among bacterial communities (Fierer et al., 2012). Different plantation forests affect soil 
460

461

462

463

464

465

466

467

468

469

470

471

472

473

474

475

476

477

478

479

480

481

482

483

484

485

486

characteristics (Bhatia., 2008), thereby causing the change in the soil microbial diversity (Nair et al., 2012), and functional diversity (Zhang et al., 2007). As a result, we believe our work has broad implications for reforestation in the semi-arid areas.

\section{Conclusions}

Our results revealed that soil characteristics after afforestation with different tree species under the same climatic conditions showed dramatic differences, especially between Populus $\times$ canadensis Moench and Pinus sylvestris var. mongolica and Pinus tabuliformis. Compared to Pinus sylvestris var. mongolica and Pinus tabuliformis, the plantation of Populus $\times$ canadensis Moench increased the soil $\mathrm{pH}$ value, DOC content, and soil available $\mathrm{P}$ content, while the $\mathrm{C} / \mathrm{N}$ ratio decreased. Furthermore, the soil bacterial community compositions, diversity, and functions are different among plantation types, especially for Populus $\times$ canadensis Moench and Pinus sylvestris var. mongolica plus Pinus tabuliformis.

The bacterial diversity indices and the relative abundances of Proteobacteria, and Chloroflexi in the soil significantly differed among plantation types. The bacterial community compositions and functional groups related to $\mathrm{C}$ and $\mathrm{N}$ cycling from Pinus sylvestris var. mongolica, and Pinus tabuliformis were grouped tightly, indicating that the phylogenetic distance for microorganisms under different plantation types could be divided into two groups, including Pinus sylvestris var. mongolica, plus Pinus tabuliformis, and Populus $\times$ canadensis Moench. Our results highlighted that the soil bacterial community compositions and functions obviously differed following afforestation, especially between Populus $\times$ canadensis Moench and Pinus sylvestris var. mongolica and Pinus tabuliformis, which in turn enormously established the correlation between the soil microbial community characteristics and the afforestation tree species. Moreover, the bacterial community structure and functions related to $\mathrm{C}$ and $\mathrm{N}$ cycling showed consistent differences among different plantation forests following afforestation in the semi-arid areas.

\section{References}

Allington GRH, Valone TJ. 2010. Reversal of desertification: The role of physical and chemical soil properties. Journal of Arid Environments 74(8): 973-977 DOI 
487

488

489

490

491

492

493

494

495

496

497

498

499

500

501

502

503

504

505

506

507

508

509

510

511

512

513

10.1016/j.jaridenv.2009.12.005.

Araujo JF, De Castro APD, Costa MM, Togawa RC, Júnior GJ, Quirino BF, Bustamante MM, Williamson L, Handelsman J, Krüger RH. 2012. Characterization of soil bacterial assemblies in Brazilian Savanna-Like vegetation reveals Acidobacteria dominance. Microbial Ecology 64(3): 760-770 DOI 10.1007/s00248-012-0057-3.

Augusto L, Ranger J, Dan B, Rothe A. 2002. Impact of several common tree species of European temperate forests on soil fertility. Annals of Forest Science 59(3): 233-253 DOI 10.1051/forest: 2002020 .

Banerjee S. 2016. Network analysis reveals functional redundancy and keystone taxa amongst bacterial and fungal communities during organic matter decomposition in an arable soil. Soil Biology Biochemistry 97: 188-198. DOI org/10.1016/j.soilbio.2016.03.017.

Bao, S.D. 2015. Soil and agricultural chemistry analysis. BeiJing: China Agriculture Press.

Becerril-Piña R, Mastachi-Loza CA, González-Sosa E, Díaz-Delgado C, Bâ KM. 2015. Assessing desertification risk in the semi-arid highlands of central Mexico. Journal of Arid Environments 120(120): 4-13 DOI 10.1016/j.jaridenv.2015.04.006.

Bent E, Németh D, Wagner-Riddle C, Dunfield KE. 2016. Residue management leading to higher field-scale $\mathrm{N}_{2} \mathrm{O}$ flux is associated with different soil bacterial nitrifier and denitrifier gene community structures. Applied Soil Ecology 108: 288-299 DOI 10.1016/j.apsoil.2016.09.008.

Bergkemper F, Welzl G, Lang F, Krüger J, Schloter M, Schulz S. 2016. The importance of C, N and $\mathrm{P}$ as driver for bacterial community structure in German beech dominated forest soils. Journal of Plant Nutrition and Soil Science 179(4): 472-480 DOI 10.1002/jpln.201600077.

Bhatia CR. 2008. Role of microbial diversity for soil, health and plant nutrition// molecular mechanisms of plant and microbe coexistence. Springer Berlin Heidelberg, 53-74.

Braak CJFT, Smilauer P. 2002. Canoco reference manual and CanoDraw for Windows User's Guide: Software for Canonical Community Ordination version 4.5. Ithaca Ny Usa Www.

Bridge P, Spooner B. 2001. Soil fungi: diversity and detection. Plant and Soil 232(1/2):147-154 DOI 10.1023/a:1010346305799. 
514 Burton J, Chen C, Xu Z, Ghadiri H. 2010. Soil microbial biomass, activity and community 515 composition in adjacent native and plantation forests of subtropical Australia. Journal of Arid 516 Environments 10(7): 1267-1277 DOI 10.1007/s11368-010-0238-y.

517 Caporaso JG, Kuczynski J, Stombaugh J, Bittinger K, Bushman FD, Costello EK. 2010. QIIME 518 allows analysis of highthroughput community sequencing data. Nature Methods. 7(5): 335$519 \quad 336$ DOI 10.1038/nmeth.f.303.

520 Chasek P, Safriel U, Shikongo S, Vivian FF. 2015. Operationalizing Zero Net Land Degradation: 521 The next stage in international efforts to combat desertification? Journal of Arid 522

Deng JJ, Yin Y, Luo JY, Zhu WX, Zhou YB. 2019. Different revegetation types alter soil physical- 
542

543

544

545

546

547

548

549

550

551

552

553

554

555

556

557

558

559

560

561

562

563

564

565

566

567

568

chemical characteristics and fungal community in the Baishilazi Nature Reserve. PeerJ 6: e6251 DOI 10.7717/peerj.6251.

Deng XP, Shan L, Zhang H, Turner NC. 2006. Improving agricultural water use efficiency in arid and semiarid areas of China. Agricultural Water Management 80(1-3): 23-40 DOI 10.1016/j.agwat.2005.07.021.

Ding X, Zhang B, Lü X, Wang J, Horwath WR. 2017. Parent material and conifer biome influence microbial residue accumulation in forest soils. Soil Biology Biochemistry 107: 1-9 DOI 10.1016/j.soilbio.2016.12.020.

Edgar RC. 2013.UPARSE: highly accurate OTU sequences from microbial amplicon reads. Nature Methods 10: 996-998 DOI 10.1038/NMETH.2604.

Emteryd O. 1989. Chemical and physical analysis of inorganic nutrients in plant, soil, water and air. Swedish University of Agricultural Sciences. Department of Forest Site Research.

Fan B, Guo L, Li N, Chen J, Lin H, Zhang X, Shen M, Rao Y, Wang C, Ma L. 2014. Earlier vegetation green-up has reduced spring dust storms. Scientific Reports. 4: 6749 DOI $10.1038 /$ srep06749.

Fierer N, Bradford MA, Jackson RB. 2007. Toward an ecological classification of soil bacteria. Ecology 88(6): 1354-1364 DOI 10.1890/05-1839.

Fierer N, Lauber CL, Ramirez KS, Zaneveld J, Bradford MA, Knight R. 2012. Comparative metagenomic, phylogenetic and physiological analyses of soil microbial communities across nitrogen gradients. Isme Journal 6(5): 1007-1017 DOI 10.1038/ismej.2011.159.

Furtado C, Macedo TBS. 2008. UN Convention to Combat Desertification: Recent Developments. Max Planck Yearbook of United Nations Law Online 19(1): 814-818 DOI 10.1016/S10036326(08)60356-8.

Gao Y, Qiu GY, Shimizu H, Tobe K, Sun B, Wang J. 2002. A 10-year study on techniques for vegetation restoration in a desertified Salt Lake area. Journal of Arid Environments 52(4): 483-497 DOI 10.1006/jare.2002.1013.

Ge X, Li Y, Luloff AE, Dong K, Xiao J. 2015. Effect of agricultural economic growth on sandy 
569

570

571

572

573

574

575

576

577

578

579

580

581

582

583

584

585

586

587

588

589

590

591

592

593

594

595

desertification in Horqin Sandy Land. Ecological Economic 119: 53-63 DOI 10.1016/j.ecolecon.2015.08.006.

Gregorich EG, Rochette P, Vandenbygaart AJ, Angers D. 2005. Greenhouse gas contributions of agricultural soils and potential mitigation practices in Eastern Canada. Soil and Tillage Research 83(1): 53-72 DOI 10.1016/j.still.2005.02.009

Gong W, Yan XY, Wang JY, Hu TX, Gong YB. 2009. Long-term manuring and fertilization effects on soil organic carbon pools under a wheat-maize cropping system in North China Plain. Plant and Soil 314(1-2), 67-76 DOI 10.1007/s11104-008-9705-2.

Gunina A, Smith AR, Godbold DL, Jones DL, Kuzyakov Y. 2017. Response of soil microbial community to afforestation with pure and mixed species. Plant and Soil 412(1-2): 357-368 DOI 10.1007/s11104-016-3073-0.

Hui L, Ye D, Wang X, Settles ML, Wang J, Hao Z Q, Zhou LS, Dong P, Jiang Y, Ma ZS. 2014. Soil bacterial communities of different natural forest types in Northeast China. Plant and Soil 383(1-2): 203-216 DOI 10.1007/s11104-014-2165-y.

Jenkins JR, Viger M, Arnold EC, Harris ZM, Ventura M, Miglietta F, Cyrii G, Edwards RJ, Rumpel C, Fornasier F, Zavalloni C, Tonon G, Alberti G, Taylor G. 2017. Biochar alters the soil microbiome and soil function: results of next-generation amplicon sequencing across Europe. GCB Bioenergy 9(3): 519-621 DOI 10.1111/gcbb.12371.

Jiang Y, Chen C, Xu Z, Liu Y. 2012. Effects of single and mixed species forest ecosystems on diversity and function of soil microbial community in subtropical China. Journal of Soils and Sediments 12(2): 228-240 DOI 10.1007/s11368-011-0442-4.

Jones RT, Robeson MS, Lauber CL, Hamady M, Knight R, Fierer N. 2009. A comprehensive survey of soil acidobacterial diversity using pyrosequencing and clone library analyses. The Isme Journal 3(4): 442-453 DOI 10.1038/ismej.2008.127.

Kang H, Gao H, Yu W, Yi Y, Wang Y, Ning M. 2018. Changes in soil microbial community structure and function after afforestation depend on species and age: Case study in a subtropical alluvial island. Science of The Total Environment 625: 1423-1432 DOI 
596

597

598

599

600

601

602

603

604

605

606

607

608

609

610

611

612

613

614

615

616

617

618

619

620

621

622

org/10.1016/j.scitotenv.2017.12.180.

Kim S, Zang H, Mortimer P, Shi LL, Li YJ, Xu JC, Ostermann A. 2018. Tree species and recovery time drives soil restoration after mining: A Chronosequence Study. Land degradation and development 29(6): 1738-1747 DOI org/10.1002/1dr.2951.

Kõljalg, U., Nilsson, R. H., Abarenkov, K., Tedersoo, L., Taylor, A. F., Bahram, M., Bates ST, Bruns TD, Bengtsson-Palme J, Callaghan TM, Douglas B, Drenkhan T, Eberhardt U, Dueñas M, Grebenc T, Griffith GW, Hartmann M, Kirk PM, Kohout P, Larsson E, Lindahl BD, Lücking R, Martín MP, Matheny PB, Nguyen NH, Niskanen T, Oja J, Peay KG, Peintner U, Peterson M, Põldmaa K, Saag L, Saar I, Schüßler A, Scott JA, Senés C, Smith ME, Suija A, Taylor DL, Telleria MT, Weiss M, Larsson KH. 2013. Towards a unified paradigm for sequence-based identification of fungi. Molecular Ecology 22(21): 5271-5277 DOI 10.1111/mec. 12481 .

Kubartová A, Moukoumi J, Béguiristain T, Ranger J, Berthelin J. 2007. Microbial diversity during cellulose decomposition in different forest stands: I. microbial communities and environmental conditions. Microbial Ecology 54(3): 393-405 DOI 10.1007/s00248-0079286-2.

Lauber CL, Hamady M, Knight R, Fierer N. 2009. Pyrosequencing-Based assessment of soil pH as a predictor of soil bacterial community structure at the continental scale. Applied and Environmental Microbiology 75(15): 5111-5120 DOI 10.1128/AEM.00335-09.

Li D, Xu D, Wang Z, Ding X, Song A. 2018. Ecological compensation for desertification control: A review. Journal of Geographical Sciences 28(3): 367-384 DOI 10.1007/s11442-018-14789.

Li MM, Liu A, Zou CJ, Xu WD, Shimizu H, Wang KR. 2012. An overview of the "Three-North" Shelterbelt project in China. Forest Ecosystems 14(1): 70-79 DOI 10.1007/s11632-012-01083.

Lin YT, Hu HW, Whitman WB, Coleman DC, Chiu CY. 2014. Comparison of soil bacterial communities in a natural hardwood forest and coniferous plantations in perhumid subtropical 
low mountains. Botanical Studies 55: 31-39 DOI [10.1186/s40529-014-0050-x].

624 Lin YT, Jangid K, Whitman WB, Coleman DC, Chiu CY. 2011. Change in bacterial community 625 structure in response to disturbance of natural hardwood and secondary coniferous forest soils

$$
\text { in Central Taiwan. Microbial Ecology 61(2): 429-437 DOI 10.1007/s00248-010-9748-9. }
$$

Liu J, Dang P, Gao Y, Zhu HL, Zhu HN, Zhao F, Zhao Z, 2018. Effects of tree species and soil properties on the composition and diversity of the soil bacterial community following afforestation. Forest Ecology and Management 427(1): 342-349 DOI org/10.1016/j.foreco.2018.06.017.

Liu J, Diamond J. 2005. China's environment in a globalizing world. Nature 435(7046): 1179 DOI $10.1038 / 4351179 a$.

Louca S, Jacques SMS, Pires APF, Leal JS, González AL, Doebeli M, Farjalla VF. 2017. Functional structure of the bromeliad tank microbiome is strongly shaped by local geochemical conditions. Environmental Microbiology 19(8): 3132-3151 DOI 10.1111/14622920.13788.

Louca S, Parfrey LW, Doebeli M. 2016. Decoupling function and taxonomy in the global ocean microbiome. Science 353(6305): 1272 DOI 10.1126/science.aaf4507.

Lozupone CA, Hamady M, Kelley ST, Knight R. 2007. Quantitative and qualitative beta diversity measures lead to different insights into factors that structure microbial communities. Applied and Environmental Microbiology 73(5): 1576-1585 DOI 10.1128/AEM.01996-06.

Lu Z, Wei Y, Li Z, Guo X, Zhou Y. 2017. Characteristics of sap flow and its influencing factors of Pinus sylvestris var. mongolica insandy land of Northwest Liaoning. Chinese Journal of Ecology 36(11): 3182-3189 DOI 10.13292/j.1000-4890.201711.020.

Lv G, Zhai JX, Li YX, Wang L, Wang YC. 2018. Soil infiltration characteristics of different plant community in sandy land of northwestern Liaoning. Agricultural Research in the Arid Areas 36(4) 133-139.

Maia SMF, Ogle SM, Cerri CEP, Cerri CC. 2010. Soil organic carbon stock change due to land use activity along the agricultural frontier of the southwestern Amazon, Brazil, between 1970 
650

651

652

653

654

655

656

657

658

659

660

661

662

663

664

665

666

667

668

669

670

671

672

673

674

675

676

and 2002. Global Change Biology 16(10): 2775-2788 DOI 10.1111/j.13652486.2009.02105.x.

Martã-Nez-Valderrama J, Ibáñez J, Del Barrio G, Sanjuán ME, Alcalá FJ, Martínez-Vicente S, Ruiz A, Puigdefábregas J. 2016. Present and future of desertification in Spain: Implementation of a surveillance system to prevent land degradation. Science of the Total Environment 563-564:169-178 DOI 10.1016/j.scitotenv.2016.04.065.

Mcgroddy ME, Daufresne T, Hedin LO. 2004. Scaling of C:N:P stoichiometry in forests worldwide: implications of terrestrial redfield-type ratios. Ecology 85(9): 2390-2401 DOI 10.1890/03-0351.

Meng H, Li K, Nie M, Wan JR, Quan ZX, Fang CM, Chen JK, Gu LD, Li B. 2013. Responses of bacterial and fungal communities to an elevation gradient in a subtropical montane forest of China. Applied Microbiology and Biotechnology 97(5): 2219-2230 DOI 10.1007/s00253-0124063-7.

Mg VDH, Bardgett RD, van Straalen NM. 2010. The unseen majority: soil microbes as drivers of plant diversity and productivity in terrestrial ecosystems. Ecology Letters 11(3): 296-310 DOI 10.1111/j.1461-0248.2007.01139.x.

Nair A, Ngouajio M. 2012. Soil microbial biomass, functional microbial diversity, and nematode community structure as affected by cover crops and compost in an organic vegetable production system. Applied Soil Ecology 58: 45-55 DOI 10.1016/j.apsoil.2012.03.008.

Nunezmir GC, Iannone BVI, CurtisK, Fei SL, Oliet JA. 2015. Evaluating the evolution of forest restoration research in a changing world: a "big literature" review. New Forest 46(5-6): 669682 DOI 10.1007/s11056-015-9503-7.

Parks DH, Tyson GW, Hugenholtz P, Beiko RG. 2014. STAMP: statistical analysis of taxonomic and functional profiles. Bioinformatics 30(21): 3123-3124 DOI: 10.1093/bioinformatics/btu494.

Peng SS, Piao S, Zeng Z, Ciais P, Zhou L, Li LZ, Li LZX, Myneni RB, Yin Y, Zeng H. 2014. Afforestation in China cools local land surface temperature. Proceedings of the National 
678

679

680

681

682

683

684

685

686

687

688

689

690

691

692

693

694

695

696

697

698

699

700

701

702

703

Piao S, Fang J, Liu H, Zhu B. 2005. NDVI-indicated decline in desertification in China in the past two decades. Geophysical Research Letters 32(6): 347-354 DOI 10.1029/2004g1021764.

Preem JK, Truu J, Truu M, Ülo M, Oopkaup K, Lõhmus K, Helmiisaari HS, Uri V, Zobel M. 2012. Bacterial community structure and its relationship to soil physico-chemical characteristics in alder stands with different management histories. Ecological Engineering 49(4): 10-17 DOI 10.1016/j.ecoleng.2012.08.034.

Qadir M, Qureshi AS, Cheraghi SAM. 2010. Extent and characterisation of salt-affected soils in Iran and strategies for their amelioration and management. Land Degradation and Development 19(2): 214-227 DOI 10.1002/ldr.818.

Qiu K, Xie Y, Xu D, Pott R. 2018. Ecosystem functions including soil organic carbon, total nitrogen and available potassium are crucial for vegetation recovery. Scientific Reports 8(1): 7607 DOI 10.1038/s41598-018-25875-x.

R Development Core Team. 2009. R: a language and environment for statistical computing. R Foundation for Statistical Computing, R Foundation for Statistical Computing, Vienna, Austria. Computing 14 12-21.

Ren C, Zhao F, Kang D, Yang G, Han X, Tong X, Feng Y, Ren G, 2016. Linkages of C:N:P stoichiometry and bacterial community in soil following afforestation of former farmland. Forest Ecology and Management 376: 59-66 DOI 10.1016/j.foreco.2016.06.004.

Reynolds JF, Smith DM, Lambin EF, Turner BL, Mortimore M, Batterbury SP, Downing TE, Dowlatabadi H, Fernández RJ, Herrick JE, Huber-Sannwald E, Jiang H, Leemans R, Lynam T, Maestre FT, Ayarza M, Walker B. 2007. Global Desertification: Building a science for dryland development. Science 316(5826): 847-851 DOI 10.1126/science.1131634.

Ritz K, Black HIJ, Campbell CD, Harris JA, Wood C. 2009. Selecting biological indicators for monitoring soils: A framework for balancing scientific and technical opinion to assist policy development. Ecological Indicators 9(6): 1212-1221 DOI 10.1016/j.ecolind.2009.02.009.

Salvati L, Mavrakis A, Colantoni A, Colantoni A, Mancino G, Ferrara A. 2015. Complex Adaptive 
704

705

706

707

708

709

710

711

712

713

714

715

716

717

718

719

720

721

722

723

724

725

726

727

728

729

730

Systems, soil degradation and land sensitivity to desertification: A multivariate assessment of Italian agro-forest landscape. Science of The Total Environment 521-522: 235-245 DOI 10.1016/j.scitotenv.2015.03.094.

Sauheitl L, Glaser B, Dippold M, Leiber K, Weigelt A. 2010. Amino acid fingerprint of a grassland soil reflects changes in plant species richness. Plant and Soil 334(1-2): 353-363 DOI 10.1007/s11104-010-0387-1.

Schrumpf M, Schulze ED, Kaiser K, Schumacher J. 2011. How accurately can soil organic carbon stocks and stock changes be quantified by soil inventories? Biogeosciences 8: 1193-1212 DOI org/10.5194/bg-8-1193-2011.

State Forest Administration. 2010. The seventh national forest resources inventory and the forest resources conditions, China. Forest Resources Management 1-8.

Sun H, Terhonen E, Koskinen K, Paulin L, Kasanen R, Asiegbua FO. 2014. Bacterial diversity and community structure along different peat soils in boreal forest. Applied Soil Ecology 74(2): 37-45 DOI 10.1016/j.apsoil.2013.09.010.

Sutton PC, Anderson SJ, Costanza R, Kubiszewski I. 2016. The ecological economics of land degradation: Impacts on ecosystem service values. Ecological Economics 129:182-192 DOI 10.1016/j.ecolecon.2016.06.016.

Tan M, Li X. 2015. Does the Green Great Wall effectively decrease dust storm intensity in China? A study based on NOAA NDVI and weather station data. Land Use Policy 43: $42-47$ DOI 10.1016/j.landusepol.2014.10.017.

Torres L, Abraham EM, Rubio C, Barbero-Sierra C, Ruiz-Pérez M. 2015. Desertification research in Argentina. Land Degradation and Development 26(5): 433-440 DOI 10.1002/ldr.2392.

Ushio M, Wagai R, Balser TC, Kitayama K. 2008. Variations in the soil microbial community composition of a tropical montane forest ecosystem: Does tree species matter? Soil Biology Biochemistry 40(10): 2699-2702 DOI 10.1016/j.soilbio.2008.06.023.

Verón SR, Paruelo JM. 2010. Desertification alters the response of vegetation to changes in precipitation. Journal of Applied Ecology 47(6): 1233-1241 DOI 10.1111/j.1365- 
2664.2010.01883.x.

Wang K, Wang D, Zhang C, Chen X, Song L. 2014. Effects of shelterbelt on soil physical and chemical properties in northwestern Liaoning Province. Journal of Northeast Forestry University 42: 77-79+99.

Wang Q, Wang C, Yu WW, Turak A, Chen D, Huang Y., Ao JH, Jiang Y, Huang ZR. 2018. Effects of nitrogen and phosphorus inputs on soil bacterial abundance, diversity, and community composition in Chinese Fir Plantations. Frontiers in Microbiology 9: 1543 DOI 10.3389/fmicb.2018.01543.

Wang YW, Chai Q, Ouyang XZ, Luo L. 2016. Soil microbial populations and enzyme activities under different sand-fixation forests in oasis-desert ecotone of Minqin Desert. Arid Land Geography 39:104-111.

Wei H, Peng C, Yang B, Song H, Li Q, Jiang L, Wei G, Wang K, Wang H, Liu S, Chen D, Li Y, Wang M. 2018. Contrasting soil bacterial community, diversity, and function in two forests in China. Frontiers in Microbiology 9: 1693 DOI 10.3389/fmicb.2018.01693.

Wijitkosum S. 2016. The impact of land use and spatial changes on desertification risk in degraded areas in Thailand. Sustainable Environment Research 26(2): 84-92 DOI 10.1016/j.serj.2015.11.004.

Wu SH, Huang BH, Gao J, Wang, SQ, Liao PC. 2019. The effects of afforestation on soil bacterial communities in temperate grassland are modulated by soil chemical properties. PeerJ 7: e6147 DOI 10.7717/peerj.6147.

Xin RL, Feng YM, Hong LX, Xin PW, Ke CK. 2004. Long-term effects of revegetation on soil water content of sand dunes in arid region of Northern China. Journal of Arid Environments 57(1): 1-16 DOI 10.1016/S0140-196303)00089-2.

Yang T, Ala M, Zhang Y, Wu J, Wang A. 2018. Characteristics of soil moisture under different vegetation coverage in Horqin Sandy Land, northern China. Plos One 13: e0198805 DOI 10.1371/journal.pone.0198805.

Yoon S, Cruz-García C, Sanford R, Ritalahti KM, Löffler FE. 2015. Denitrification versus 
758

759

760

761

762

763

764

765

766

767

768

769

770

771

772

773

774

775

776

777

778

779

780

781

782

783

784

respiratory ammonification: environmental controls of two competing dissimilatory NO3()/NO2(-) reduction pathways in Shewanella loihica strain PV-4. The ISME Journal 9(5): 1093-1104 DOI 10.1038/ismej.2014.201.

Yoshimura C, Gessner M, Tockner K, Furumai H. 2008. Chemical properties, microbial respiration, and decomposition of coarse and fine particulate organic matter. Journal of the North American Benthological Society 27(3): 664-673 DOI 10.1899/07-106.1.

Zaura E, Keijser BJ, Huse SM, Crielaard W. 2009. Defining the healthy "core microbiome" of oral microbial communities. Bmc Microbiology 9(1): 1-1. DOI 10.1186/1471-2180-9-259.

Zhang F, Xing Z, Rees HW, Dong Y, Li S, Meng FR. 2014. Assessment of effects of two runoff control engineering practices on soil water and plant growth for afforestation in a semi-arid area after 10 years. Ecological Engineering 64: 430-442 DOI 10.1016/j.ecoleng.2013.12.024.

Zhang Y, Zhang X, Liu X, Xiao Y, Qu L, Wu L, Zhou J. 2007. Microarray-based analysis of changes in diversity of microbial genes involved in organic carbon decomposition following land use/cover changes. FEMS microbiology letters 266(2): 144-151 DOI 10.1111/j.15746968.2006.00511.x.

Zhang Y, Peng C, Li W, Tian L, Zhu Q, Chen H, Fang X, Zhang L, Mu X, Li Z, Li S, Yang Y, Wang J, Xiao X. 2016. Multiple afforestation programs accelerate the greenness in the 'Three North' region of China from 1982 to 2013. Ecological Indicators 61: 404-412 DOI 10.1016/j.ecolind.2015.09.041.

Zhao HL, Li J, Liu RT, Zhou RL, Qu H. 2014. Effects of desertification on temporal and spatial distribution of soil macro-arthropods in Horqin sandy grassland, Inner Mongolia. Geoderma 223-225: 62-67. DOI 10.1016/j.geoderma.2014.01.026.

Zhao H, Li X, Zhang Z, Zhao Y, Yang J, Zhu Y. 2017. Species diversity and drivers of arbuscular mycorrhizal fungal communities in a semi-arid mountain in China. PeerJ, 5: e4155 DOI 10.7717/peerj.4155.

Zhao H, Li X, Zhang Z, Zhao Y, Chen P, Zhu YW. 2018. Drivers and assemblies of soil eukaryotic microbes among different soil habitat types in a semi-arid mountain in China. PeerJ 6: e6042 
DOI 10.7717/peerj.6042.

786

787

788

789

790

791

792

793

794

795

796

797

798

799

800

801

802

803

804

805

806

807

808

809

810

811

Zhong Y, Yan W, Shang GZ. 2015. Impact of long-term N additions upon coupling between soil microbial community structure and activity, and nutrient-use efficiencies. Soil Biology and Biochemistry 91:151-159 DOI 10.1016/j.soilbio.2015.08.030.

Zhou W, Lewis BJ, Wu S, Yu D, Zhou L, Wei YW, Dai LM. 2014. Biomass carbon storage and its sequestration potential of afforestation under natural forest protection program in China. Chinese Geographical Science 24(4):406-413 DOI 10.1007/s11769-014-0702-5.

Zhou YB, Guo XW, Wei YW, Wang X, Li J, Li ZY, Zheng ZR. 2016. The vertical distribution of soil carbon, nitrogen and phosphorus for typical plantations in the Semi-arid Areas of Northwest Liaoning. Journal of Shenyang Agricultural University 47: 418-424.

Zimmermann J, Gonzalez JM, Saiz-Jimenez C, Ludwig W. 2005. Detection and phylogenetic relationships of highly diverse uncultured Acidobacterial communities in Altamira Cave using 23S rRNA sequence analyses. Geomicrobiology Journal 22(7): 379-388 DOI $10.1080 / 01490450500248986$.

Zou XY, Li S, Zhang CL, Dong GR, Dong YX, Yan P. 2002. Desertification and control plan in the Tibet Autonomous Region of China. Journal of Arid Environments 51(2): 183-198 DOI 10.1006/jare.2001.0943.

Zuo X, Zhao H, Zhao X, Guo Y, Li Y, Luo Y. 2008. Plant distribution at the mobile dune scale and its relevance to soil properties and topographic features. Environmental Geology 54(5): 1111-1120 DOI 10.1007/s00254-007-1104-0.

Zuo X, Zhao X, Zhao H, Zhang T, Guo Y, Li YQ, Huang YX. 2009. Spatial heterogeneity of soil properties and vegetation-soil relationships following vegetation restoration of mobile dunes in Horqin Sandy Land, Northern China. Plant and Soil 318(1-2): 53-167 DOI 10.1007/s11104-008-9826-7.

Zuo X, Zhao X, Zhao H, Zhang T, Li Y, Li YQ, Wang S, Li W, Powers R. 2012. Scale dependent effects of environmental factors on vegetation pattern and composition in Horqin Sandy Land, Northern China. Geoderma 173-174(1-9): 1-9 DOI 10.1016/j.geoderma.2011.10.003. 
Figure 1

Location of three forest type sites.

A: Stusy site; B: Populus $\times$ canadensis Moench; C: Pinus sylvestris var. mongolica; D: Pinus tabuliformis.

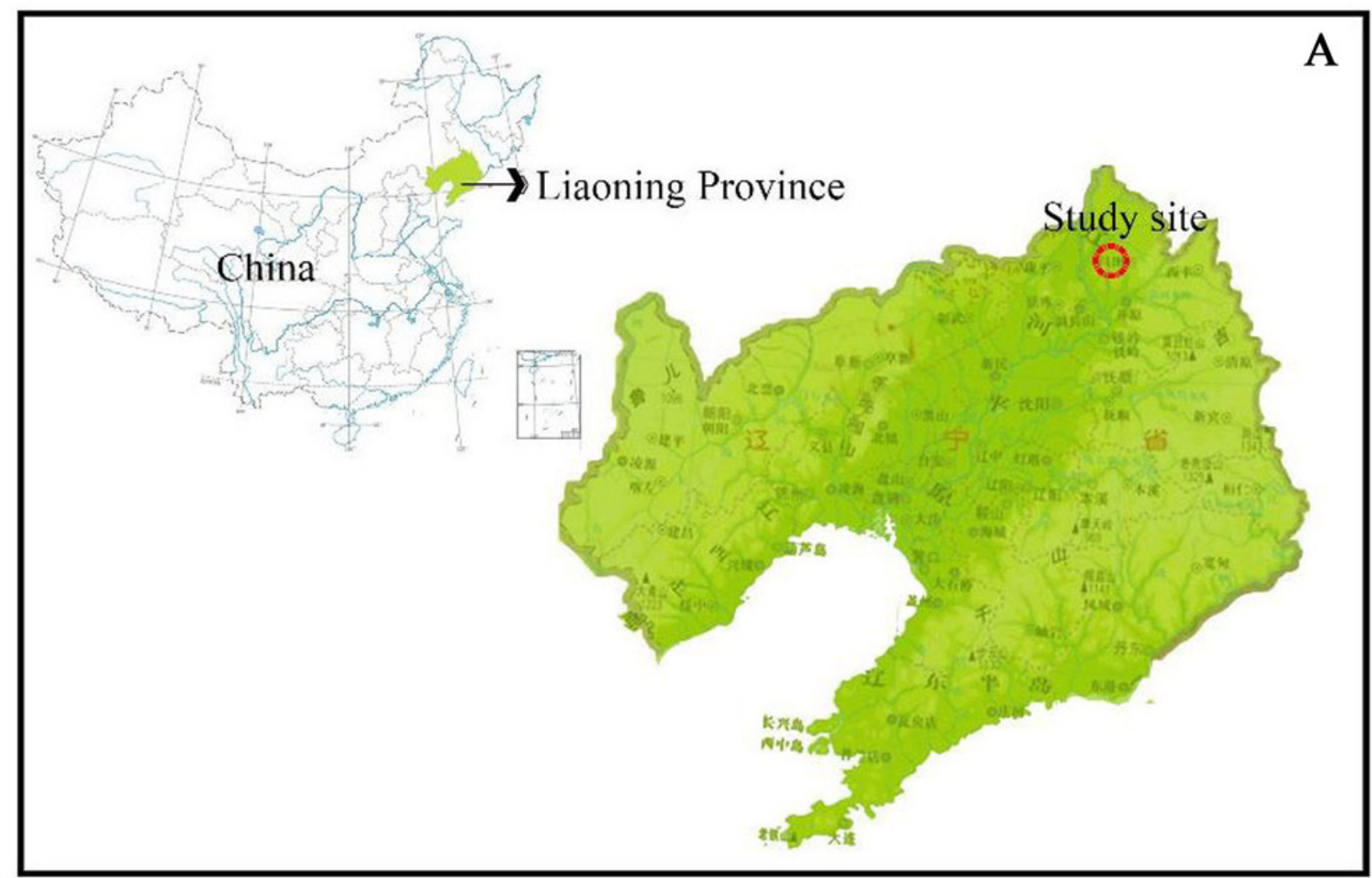

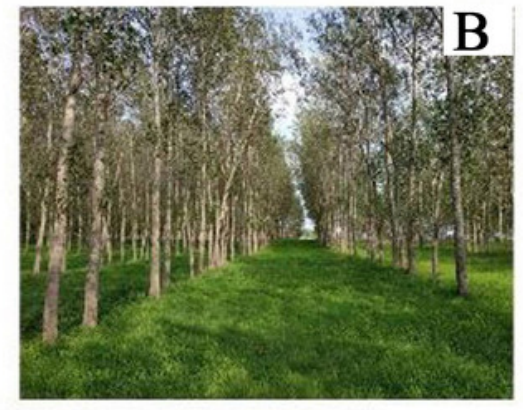

Populus $\times$ canadensis Moench

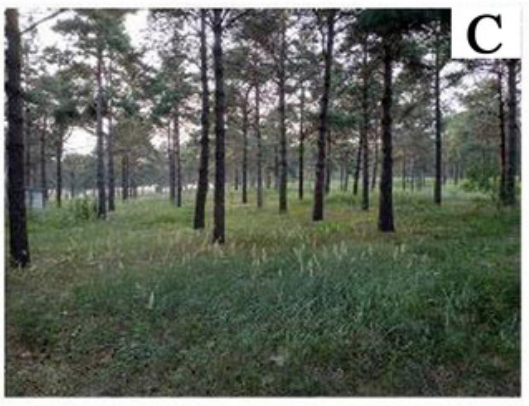

Pinus sylvestris var. mongolica

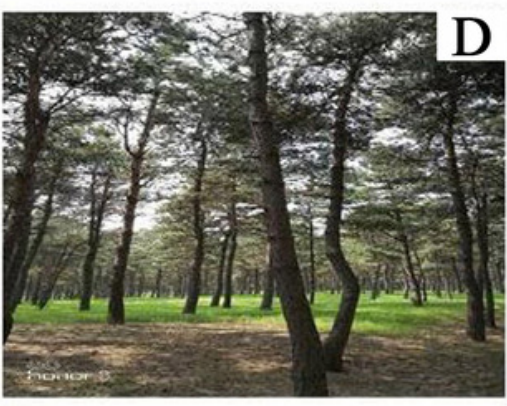

Pinus tabuliformis 
Figure 2

Results of canonical correspondence analysis-plot of all the measured soil environment factors.

PC: Populus $\times$ canadensis Moench; PS: Pinus sylvestris var. mongolica; PT: Pinus tabuliformis.

TC: total C; DOC: Dissolved organic carbon; TN: total N; AP: available P.

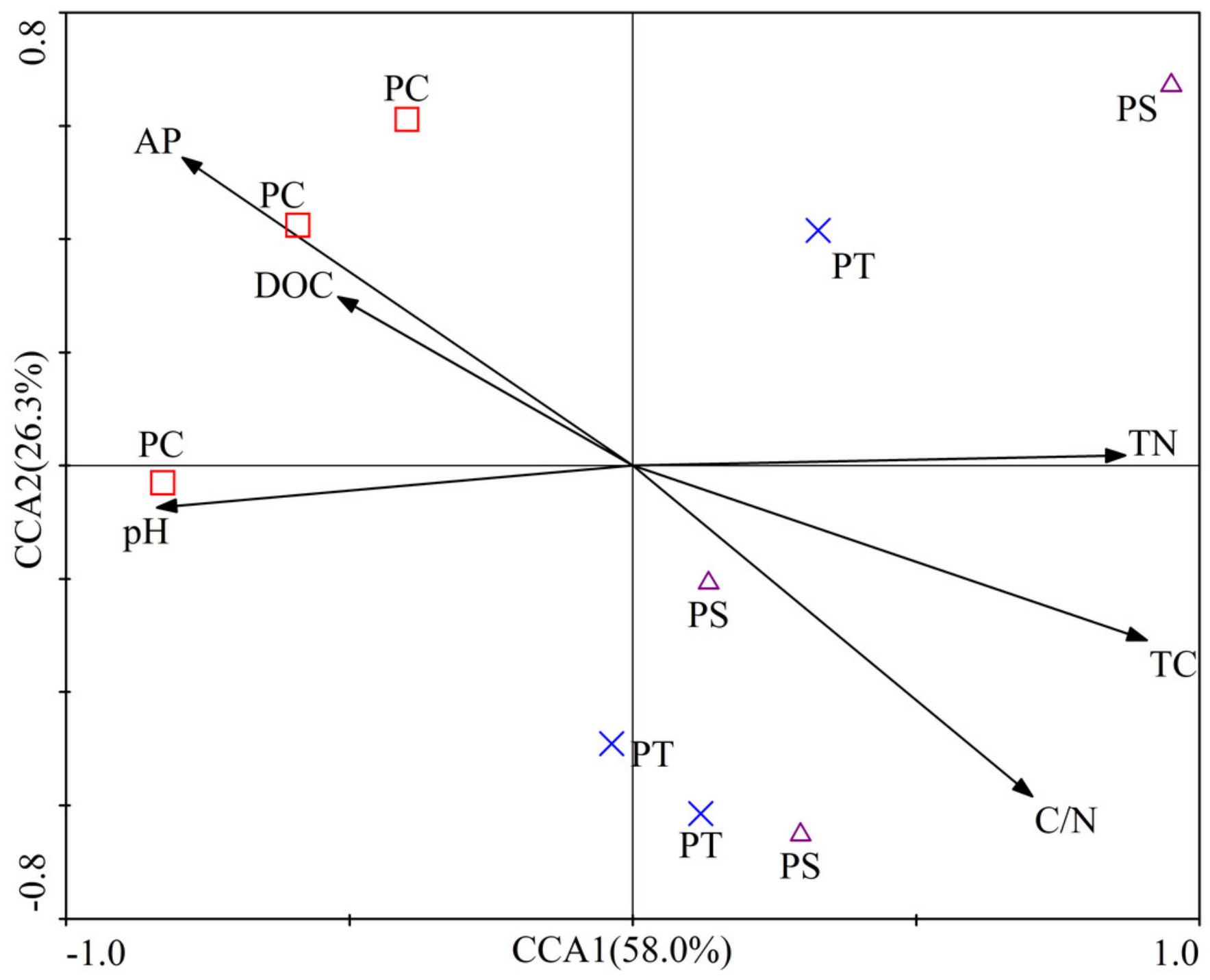




\section{Figure 3}

Venn diagram representation of shared and unique OTUs of soil bacteria across three different plantation forests.

PC: Populus $\times$ canadensis Moench; PS: Pinus sylvestris var. mongolica; PT: Pinus tabuliformis.

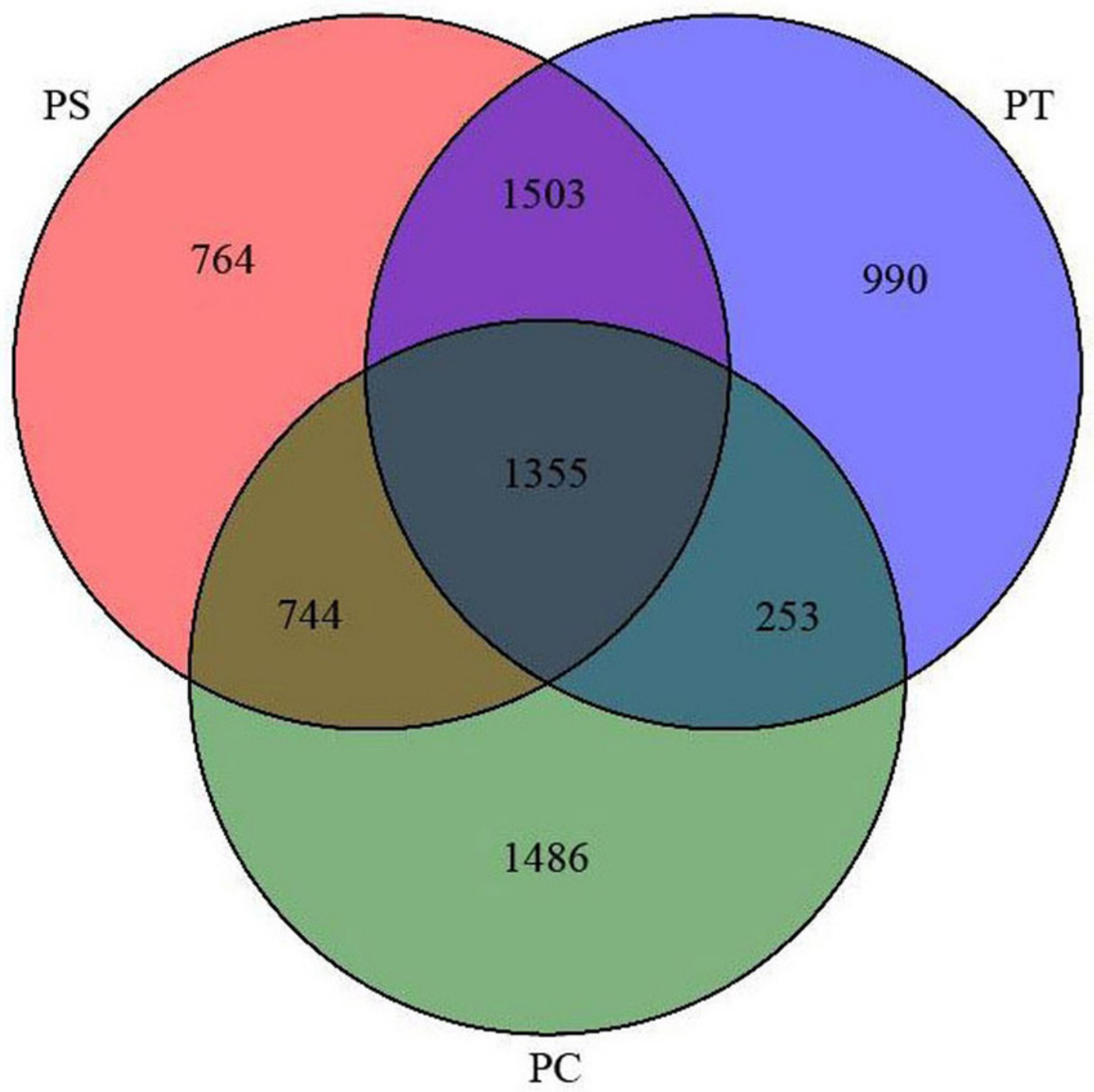


Figure 4

The relative abundance of dominant bacterial phyla (A) and genera (B) in different plantation forests.

PC: Populus $\times$ canadensis Moench; PS: Pinus sylvestris var. mongolica; PT: Pinus tabuliformis. Different small letters meant significant difference at 0.05 level. 


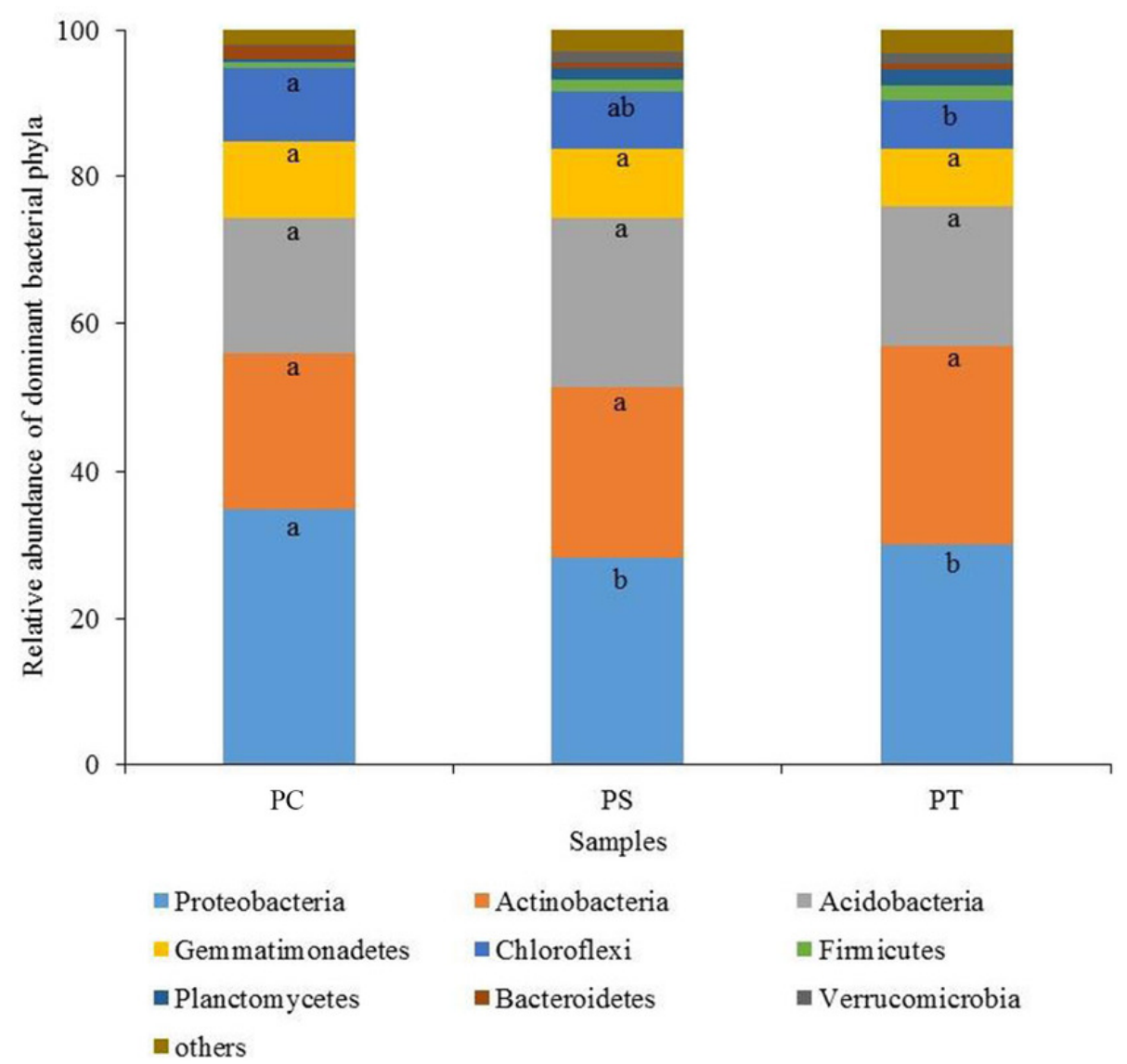

A

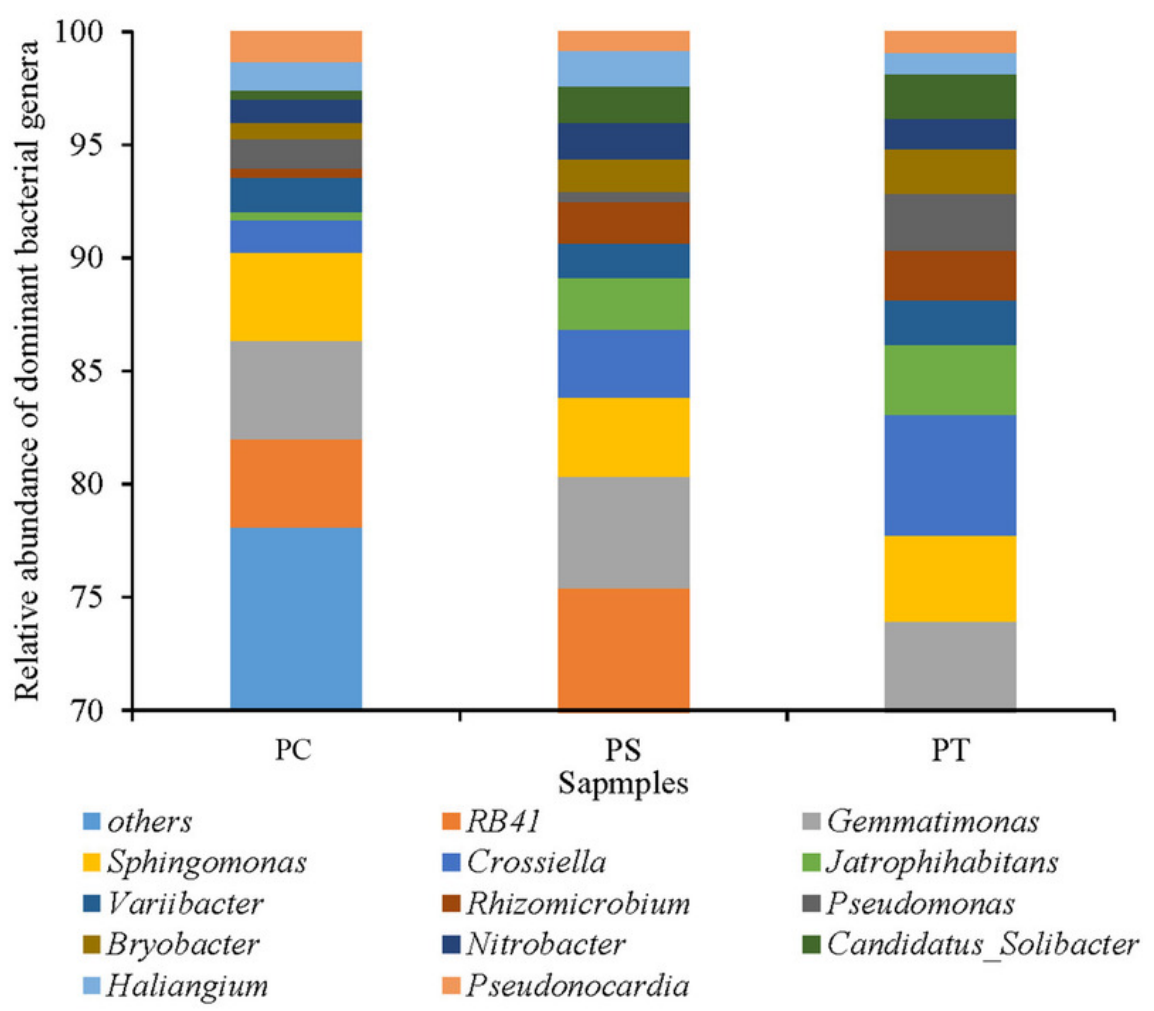

B 


\section{Figure 5}

Heatmap and hierarchical cluster analysis based on the relative abundances of the top 50 genera identified in the soil bacterial communities.

The samples are grouped according to the similarity of each other, and the clustering results are arranged horizontally according to the clustering results. In the figure, red represents the genus with higher abundance in the corresponding sample, and blue represents the genus with lower abundance. PC: Populus $\times$ canadensis Moench; PS: Pinus sylvestris var. mongolica; PT: Pinus tabuliformis. 


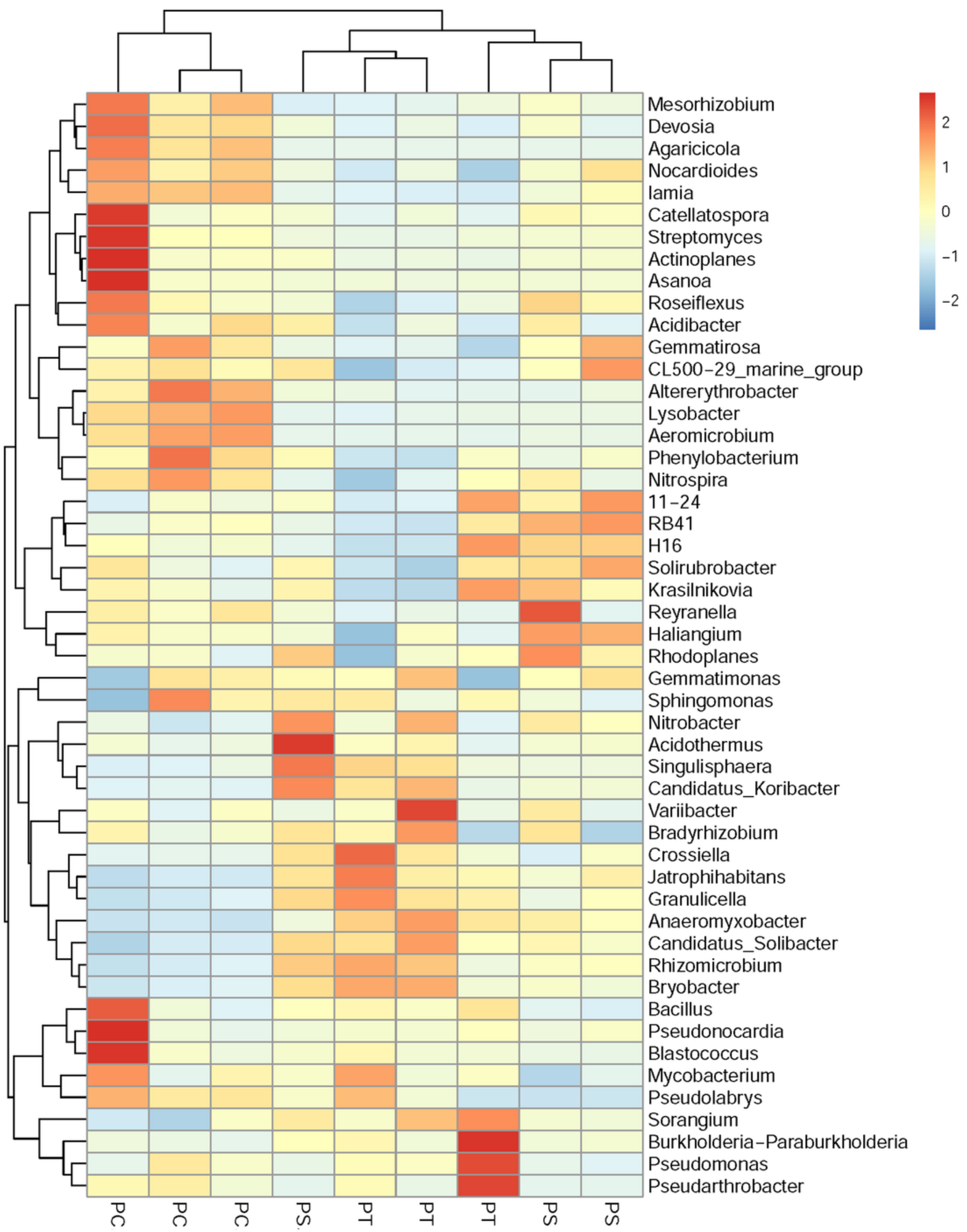


Figure 6

Non-metric Multidimensional scaling analysis (NMDS) based on unweighted Unifrac metric illustrating the soil bacterial community structure among different plantation forests.

PC: Populus $\times$ canadensis Moench; PS: Pinus sylvestris var. mongolica; PT: Pinus tabuliformis.

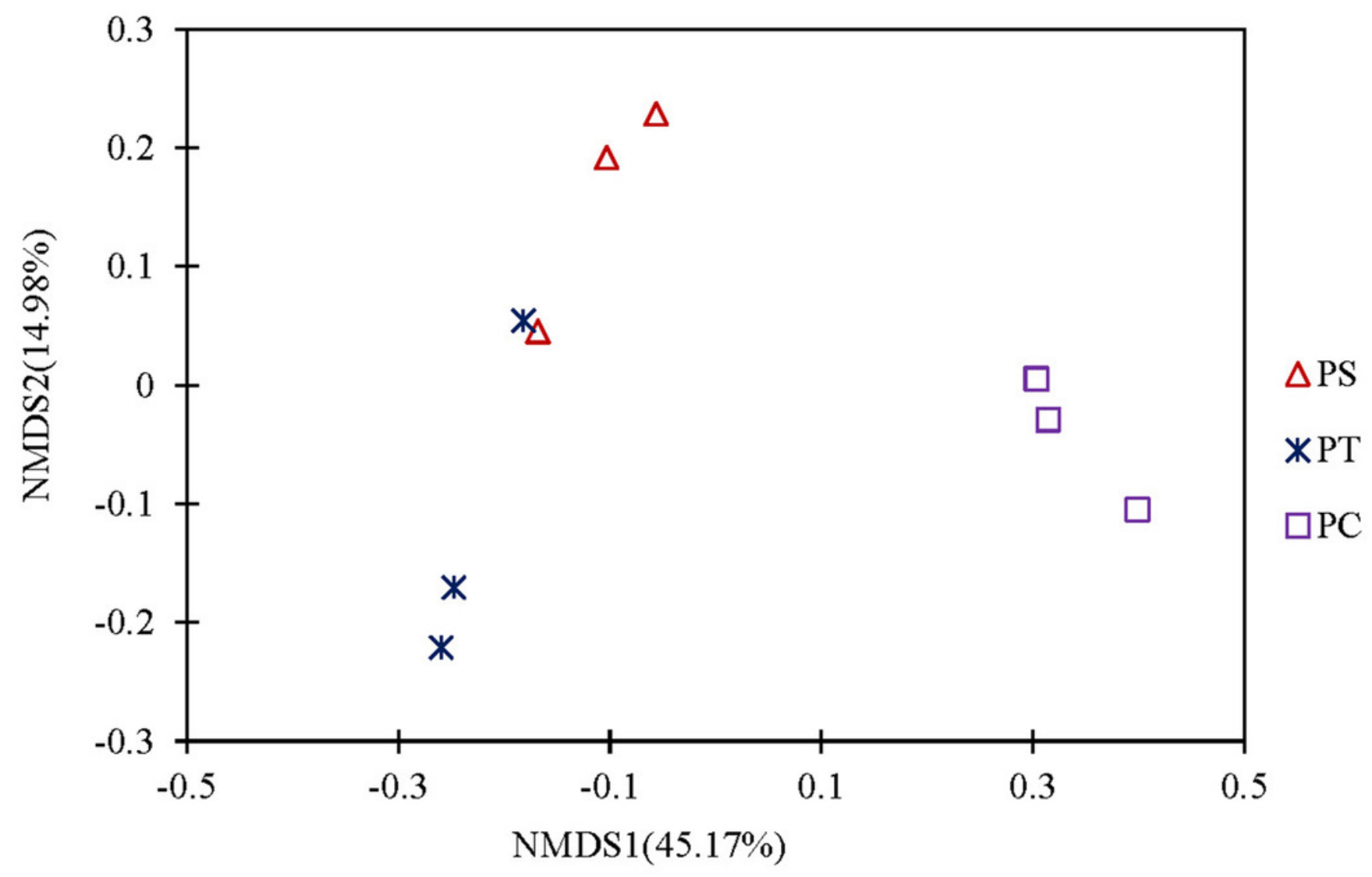


Figure 7

CCA of abundant bacterial communities at the phylum (A) and genus (B) level and soil chemical characteristics for soil samples from different plantation forests.

TC: total C; DOC: dissolved organic carbon; TN: total N; AP: available P. 

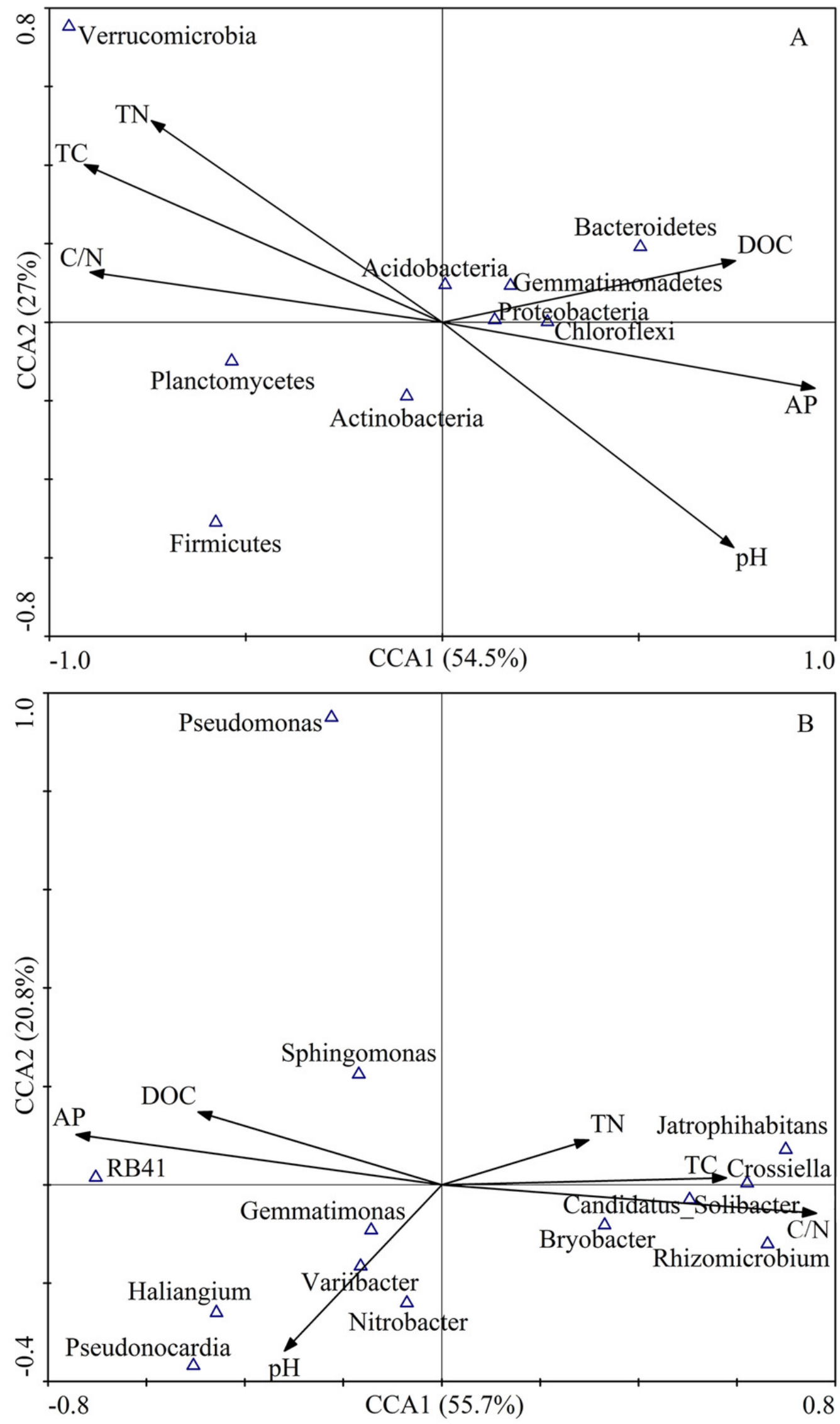
Figure 8

PCA plot of functional groups related to $\mathrm{C}$ cycling (A) and N cycling (B).

PC: Populus $\times$ canadensis Moench; PS: Pinus sylvestris var. mongolica; PT: Pinus tabuliformis. 


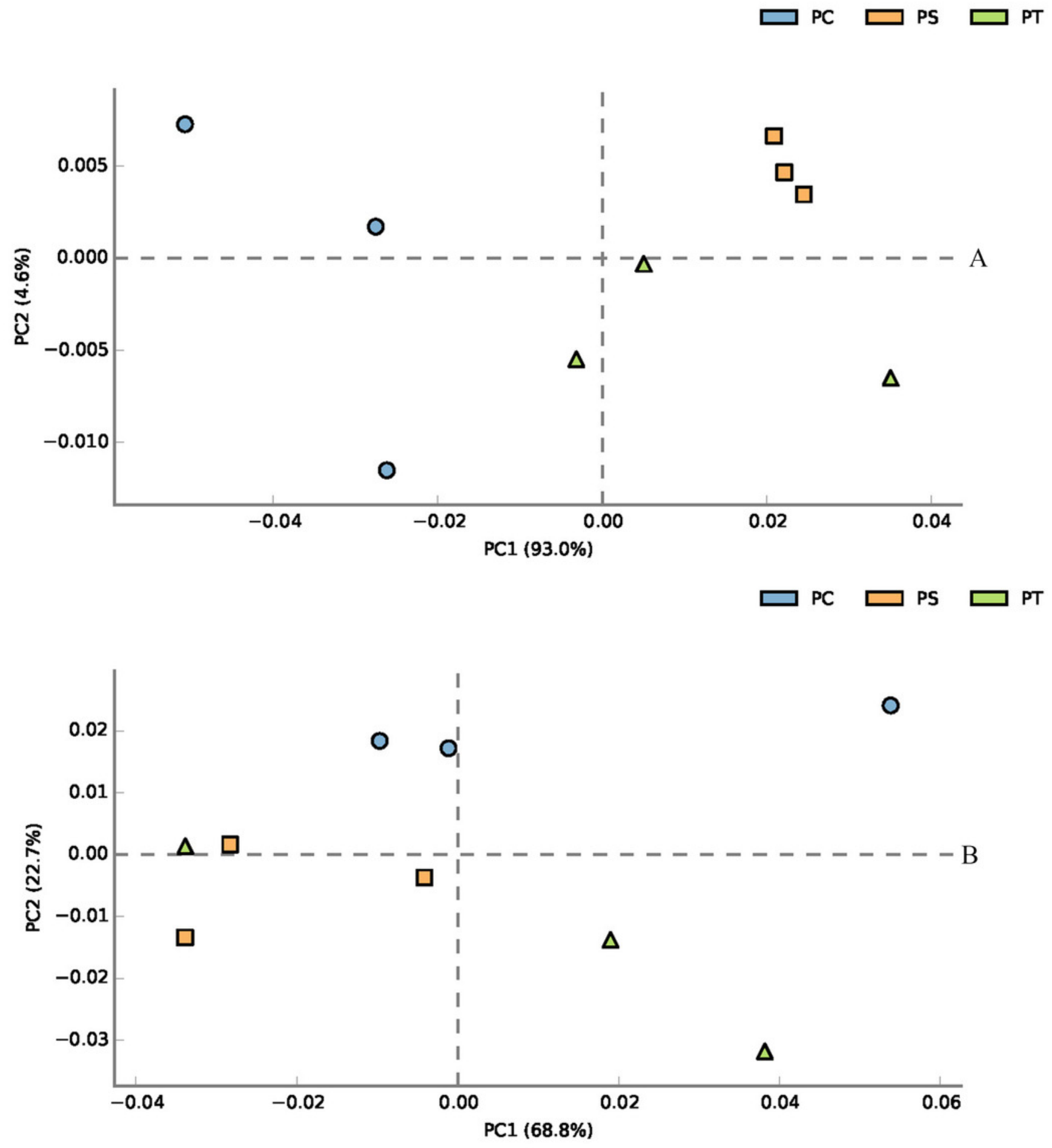


Figure 9

The relationships between soil bacterial functional groups related to $C(A)$ and $N(B)$ cycles and soil environmental factors.

TC: total C; DOC: dissolved organic carbon; TN: total N; AP: available P. 


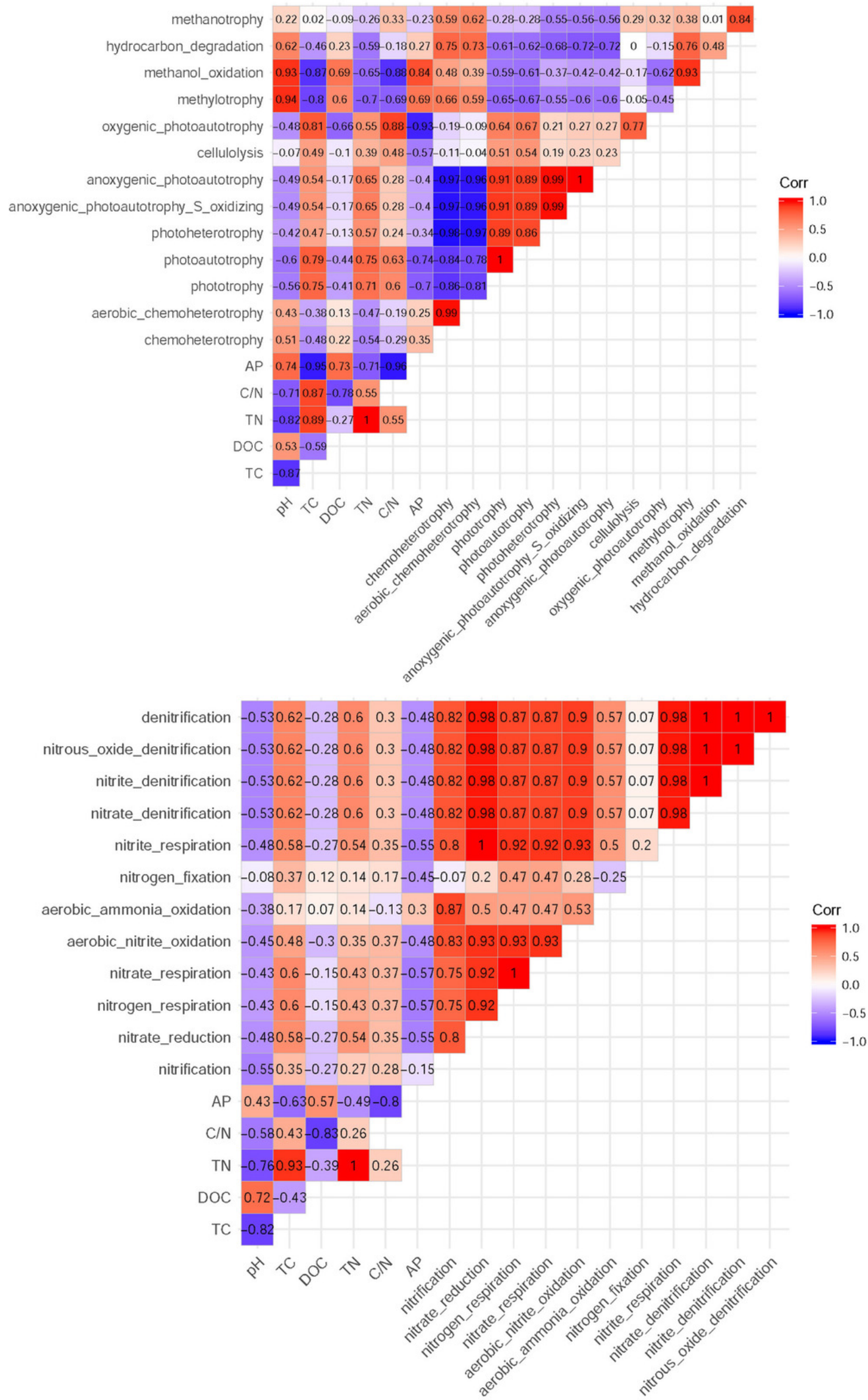

A

B 


\section{Table $\mathbf{1}$ (on next page)}

Site information.

PC: Populus $\times$ canadensis Moench; PS: Pinus sylvestris var. mongolica; PT: Pinus tabuliformis. 
1 Table 1

2 Site information.

\begin{tabular}{|c|c|c|c|c|c|}
\hline $\begin{array}{c}\text { Different } \\
\text { samples }\end{array}$ & Age of stand & $\begin{array}{c}\text { Stand density } \\
\left(\text { plant } \cdot \mathrm{hm}^{-1}\right)\end{array}$ & Height $(\mathrm{m})$ & $\begin{array}{c}\text { Diameter at breast } \\
\text { height }(\mathrm{cm})\end{array}$ & $\begin{array}{c}\text { Crown density } \\
(\%)\end{array}$ \\
\hline PC & 18 & 773 & 15.34 & 14.32 & $65 \%$ \\
\hline PS & 33 & 642 & 14.52 & 22.43 & $70 \%$ \\
\hline PT & 33 & 575 & 13.56 & 20.51 & $65 \%$ \\
\hline
\end{tabular}

3 Note:

4 PC: Populus $\times$ canadensis Moench; PS: Pinus sylvestris var. mongolica; PT: Pinus tabuliformis. 


\section{Table 2 (on next page)}

Results of MANOVA and post-hoc analyses on the effects of tree species and their interactions on soil properties.

PC: Populus $\times$ canadensis Moench; PS: Pinus sylvestris var. mongolica; PT: Pinus tabuliformis. Different small letters meant significant difference at 0.05 level. 
1 Table 2

2 Results of MANOVA and post-hoc analyses on the effects of tree species and their interactions on soil properties.

\begin{tabular}{|c|c|c|c|c|c|c|}
\hline Factors & $\mathrm{pH}$ & Total C & DOC & Total N & C/N ratio & Available P \\
\hline Tree species & -- & -- & -- & -- \\
\hline F-value & 6.58 & 30.54 & 6.02 & 6.47 & 45.49 & 78.06 \\
\hline P-value & 0.031 & 0.001 & 0.037 & 0.032 & $<0.001$ & $<0.001$ \\
\hline PC & $5.92 \mathrm{a}$ & $7.82 \mathrm{~b}$ & $105.46 \mathrm{a}$ & $0.85 \mathrm{~b}$ & $9.15 \mathrm{~b}$ & $16.00 \mathrm{a}$ \\
\hline PS & $5.57 \mathrm{~b}$ & $12.00 \mathrm{a}$ & $83.42 \mathrm{ab}$ & $1.05 \mathrm{a}$ & $11.41 \mathrm{a}$ & $3.77 \mathrm{~b}$ \\
\hline PT & $5.53 \mathrm{~b}$ & $11.46 \mathrm{a}$ & $80.10 \mathrm{~b}$ & $0.97 \mathrm{a}$ & $11.79 \mathrm{a}$ & $3.09 \mathrm{~b}$ \\
\hline
\end{tabular}

3 Note:

4 PC: Populus $\times$ canadensis Moench; PS: Pinus sylvestris var. mongolica; PT: Pinus tabuliformis. Different small letters meant significant 5 difference at 0.05 level. 


\section{Table 3 (on next page)}

Soil bacterial diversity indices in different plantation forests.

Data are means \pm standard error $(n=3)$. PC: Populus $\times$ canadensis Moench; PS: Pinus sylvestris var. mongolica; PT: Pinus tabuliformis. Different small letters meant significant difference at 0.05 level. Different capital letters meant significant difference at 0.01 level. 
1 Table 3

2 Soil bacterial diversity indices in different plantation forests.

\begin{tabular}{|c|c|c|c|c|c|}
\hline Diversity indices & PC & PS & PT & F test & $P$ value \\
\hline No. of sequences & $48848 \pm 3650 \mathrm{aA}$ & $51532 \pm 2892 \mathrm{aA}$ & $52395 \pm 2529 \mathrm{aA}$ & 1.10 & 0.39 \\
\hline $\begin{array}{c}\text { OTUs number } \\
\text { (Phylum) }\end{array}$ & $2750 \pm 349 \mathrm{bA}$ & $3378 \pm 150 \mathrm{aA}$ & $2837 \pm 141 \mathrm{bA}$ & 6.36 & 0.03 \\
\hline Shannon index & $10.46 \pm 0.11 \mathrm{aA}$ & $10.48 \pm 0.16 \mathrm{aA}$ & $10.09 \pm 0.16 \mathrm{bA}$ & 6.89 & 0.03 \\
\hline ACE index & $2898.70 \pm 537.94 \mathrm{bB}$ & $4074.80 \pm 181.79 \mathrm{aA}$ & $3192.86 \pm 344.77 \mathrm{bAB}$ & 7.64 & 0.02 \\
\hline Chaol index & $2876.13 \pm 518.02 \mathrm{bB}$ & $3952.39 \pm 67.89 \mathrm{aA}$ & $3140.32 \pm 290.58 \mathrm{bAB}$ & 7.92 & 0.02 \\
\hline Simpson index & $0.998 \pm 0.000 \mathrm{aA}$ & $0.997 \pm 0.001 \mathrm{abA}$ & $0.996 \pm 0.001 \mathrm{bA}$ & 5.68 & 0.04 \\
\hline
\end{tabular}

Data are means \pm standard error $(\mathrm{n}=3)$. PC: Populus $\times$ canadensis Moench; PS: Pinus sylvestris var. mongolica; PT: Pinus tabuliformis. Different small letters meant significant difference at 0.05 level. Different capital letters meant significant difference at 0.01 level. 


\section{Table 4 (on next page)}

Spearman's rank correlations between the soil bacterial diversity indices and available edaphic factors.

${ }^{*}$ correlation significant at 0.05 level (two-tailed), ${ }^{* *}$ correlation significant at 0.01 level (twotailed). 
1 Table 4

2 Spearman's rank correlations between the soil bacterial diversity indices and available edaphic

3 factors.

\begin{tabular}{|l|l|l|l|l|l|l|}
\hline & $\mathrm{pH}$ & Total C & $\mathrm{DOC}$ & Total N & $\mathrm{C} / \mathrm{N}$ ratio & Available P \\
\hline Simpson index & 0.65 & -0.65 & $0.67^{*}$ & -0.55 & $-0.73^{*}$ & $0.77^{*}$ \\
\hline Chao1 index & -0.48 & 0.55 & -0.35 & $0.78^{*}$ & 0.25 & -0.43 \\
\hline ACE index & -0.58 & 0.62 & -0.43 & $0.83^{* *}$ & 0.30 & -0.45 \\
\hline Shannon index & 0.22 & -0.18 & 0.27 & -0.09 & -0.35 & 0.20 \\
\hline
\end{tabular}

4 Note:

$5 *$ correlation significant at 0.05 level (two-tailed), **correlation significant at 0.01 level (two6 tailed). 


\section{Table 5 (on next page)}

Spearman's rank correlations between the relative abundances of dominant bacterial groups and available edaphic factors.

${ }^{*}$ correlation significant at 0.05 level; ${ }^{*}$ correlation significant at 0.01 level (two-tailed). 
1 Table 5

2 Spearman's rank correlations between the relative abundances of dominant bacterial groups and

3 available edaphic factors.

\begin{tabular}{|l|l|l|l|l|l|l|}
\hline & $\mathrm{pH}$ & Total C & $\mathrm{DOC}$ & Total N & $\mathrm{C} / \mathrm{N}$ ratio & Available $\mathrm{P}$ \\
\hline Proteobacteria & 0.60 & -0.55 & $0.83^{* *}$ & -0.58 & $-0.67^{*}$ & $0.68^{*}$ \\
\hline Actinobacteria & -0.25 & 0.15 & -0.55 & 0.18 & 0.23 & -0.15 \\
\hline Acidobacteria & -0.17 & 0.27 & -0.05 & 0.28 & 0.23 & -0.35 \\
\hline Gemmatimonadetes & 0.35 & -0.25 & 0.55 & -0.17 & -0.32 & 0.20 \\
\hline Chloroflexi & 0.52 & -0.63 & 0.55 & -0.52 & $-0.68^{*}$ & $0.78^{*}$ \\
\hline Firmicutes & -0.33 & 0.40 & -0.53 & 0.33 & 0.38 & -0.43 \\
\hline Planctomycetes & -0.35 & 0.60 & -0.40 & 0.33 & $0.70^{*}$ & $-0.88^{* *}$ \\
\hline Bacteroidetes & 0.40 & -0.32 & $0.78^{*}$ & -0.28 & $-0.77^{*}$ & $0.70^{*}$ \\
\hline Verrucomicrobia & $-0.83^{* *}$ & $0.90^{* *}$ & -0.50 & $0.83^{* *}$ & 0.53 & -0.58 \\
\hline
\end{tabular}

4 Note:

$5 *$ correlation significant at 0.05 level; **correlation significant at 0.01 level (two-tailed). 